\title{
Effect of Fusarium-Derived Metabolites on the Barrier Integrity of Differentiated Intestinal Porcine Epithelial Cells (IPEC-J2)
}

\author{
Alexandra Springler ${ }^{1,2}$, Galina-Jacqueline Vrubel ${ }^{1}$, Elisabeth Mayer ${ }^{1}$, Gerd Schatzmayr ${ }^{1}$ and \\ Barbara Novak 1,* \\ 1 BIOMIN Research Center, Technopark 1, Tulln an der Donau 3430, Austria; \\ alexandra.springler@biomin.net (A.S.); gala.vrubel@gmail.com (G.-J.V.); e.mayer@biomin.net (E.M.); \\ gerd.schatzmayr@biomin.net (G.S.) \\ 2 Department of Applied Genetics and Cell Biology, University of Natural Resources and Life Sciences, \\ Vienna 1190, Austria \\ * Correspondence: barbara.novak@biomin.net; Tel.: +43-2272-81166-13480
}

Academic Editors: Marc Maresca and Isabelle Oswald

Received: 20 September 2016; Accepted: 15 November 2016; Published: 19 November 2016

\begin{abstract}
The human, animal and plant pathogen Fusarium, which contaminates agricultural commodities worldwide, produces numerous secondary metabolites. An example is the thoroughly-investigated deoxynivalenol (DON), which severely impairs gastrointestinal barrier integrity. However, to date, the toxicological profile of other Fusarium-derived metabolites, such as enniatins, beauvericin, moniliformin, apicidin, aurofusarin, rubrofusarin, equisetin and bikaverin, are poorly characterized. Thus we examined their effects-as metabolites alone and as metabolites in combination with $\mathrm{DON}$ - on the intestinal barrier function of differentiated intestinal porcine epithelial cells (IPEC-J2) over $72 \mathrm{~h}$. Transepithelial electrical resistance (TEER) was measured at 24-h intervals, followed by evaluation of cell viability using neutral red (NR) assay. Enniatins A, A1, B and B1, apicidin, aurofusarin and beauvericin significantly reduced TEER. Moniliformin, equisetin, bikaverin and rubrofusarin had no effect on TEER. In the case of apicidin, aurofusarin and beauvericin, TEER reductions were further substantiated by the addition of otherwise no-effect DON concentrations. In all cases, viability was unaffected, confirming that TEER reductions were not due to compromised viability. Considering the prevalence of mycotoxin contamination and the diseases associated with intestinal barrier disruption, consumption of contaminated food or feed may have substantial health implications.
\end{abstract}

Keywords: emerging mycotoxin; transepithelial electrical resistance; IPEC-J2; deoxynivalenol; intestinal barrier function

\section{Introduction}

Mycotoxins are secondary metabolites produced by filamentous fungi, such as those of Aspergillus, Penicillium and Fusarium species [1]. Environmental conditions, improper harvesting, storage and processing operations all contribute to mycotoxin contamination of food and feed, which affects approximately $72 \%$ of agricultural commodities worldwide [2]. Mycotoxin occurrence, toxicity and appropriate detoxification strategies have been subject to a great amount of research, although with a primary focus on traditional mycotoxins, including trichothecenes, fumonisins and aflatoxins. The enormous advances of analytical methods and the development of multi-toxin methods have however enabled the detection of a large number of other fungal metabolites. The potential toxicological relevance of these metabolites must therefore be established, and if necessary, appropriate legislative regulations must be put in place $[3,4]$. The sensitive simultaneous detection of multiple 
fungal metabolites via liquid chromatography-tandem mass spectroscopy (LC-MS/MS) [5], has aided the discovery of new fungal secondary metabolites, so called "emerging mycotoxins". These occur frequently and in high concentrations in cereals and cereal-derived products [6,7]. In particular, the Fusarium species—a very common agricultural contaminant-produces a large number of secondary metabolites, which occur with varying prevalence. These include compounds such as enniatins, beauvericin, apicidin, aurofusarin and moniliformin [8]. As these have only been discovered over the last few decades, they are-to date-poorly investigated. Consequently, there is a lack of in vitro and in vivo data regarding their toxicological relevance.

With respect to the latter, the epithelium of the gastrointestinal tract is of particular significance. Due to the oral route of consumption of these compounds through contaminated food and feed, the intestinal epithelium presents the initial barrier of defense and thus a crucial toxicological target. Impairments of the intestinal barrier function lead to increased epithelial permeability and thus the uncontrolled transport of bacterial and viral pathogens, as well as food- and feed-borne toxins. This can trigger nonspecific inflammatory responses and an overstimulation of the gut associated immune system, which can negatively affect parameters such as growth performance and feed conversion rate $[9,10]$. The harmful effect of mycotoxins on the intestinal epithelial barrier function is particularly well illustrated by the example of the trichothecene deoxynivalenol (DON). Its detrimental effects on epithelial barrier function have been studied in diverse intestinal models, showing decreases in transepithelial electrical resistance (TEER) - an indicator of intestinal barrier integrity-in Caco-2 [11,12], intestinal porcine epithelial cells (IPEC)-1 [13,14] and IPEC-J2 [15,16]. Therefore, the present study-for the first time-identifies potentially harmful effects of other Fusarium metabolites on gastrointestinal barrier function.

Following the request of the European Commission, the European Food Safety Authority (EFSA) has issued a scientific opinion on the risk to human and animal health related to the presence of beauvericin and enniatins in food and feed [17]. According to this document, enniatins were found in $37 \%, 68 \%$ and $76 \%$ of food $(n=4251)$, feed $(n=3640)$ and unprocessed grain $(n=2647)$ samples, collected in 12 European countries between 2000 and 2013. In cereal-based products, maximum concentrations were 42, 125, 832 and $980 \mu \mathrm{g} / \mathrm{kg}$ for enniatin A, A1, B, and B1, respectively. In grains, the maximum reported concentrations were $950,2000,18,300$ and $5720 \mu \mathrm{g} / \mathrm{kg}$ for enniatin A, A1, B, and B1, respectively. Beauvericin was found in $20 \%, 21 \%$ and $54 \%$ in food $(n=732)$, feed $(n=861)$ and unprocessed grain $(n=554)$, respectively [17]. Maximum concentrations of beauvericin in grains and in cereal-based food were 6400 and $844 \mu \mathrm{g} / \mathrm{kg}$, respectively. According to Streit et al. [8], enniatins and beauvericin were found in $96 \%$ of feed and $98 \%$ of feed raw material samples (both $n=83$ ) with median and maximum concentrations of 30 and $5441 \mu \mathrm{g} / \mathrm{kg}$ for enniatins and $6.7 \mu \mathrm{g} / \mathrm{kg}$ and $2330 \mu \mathrm{g} / \mathrm{kg}$ for beauvericin, respectively. Toxicity of enniatins and beauvericin is based on their ionophoric properties, which enables the passage of mono- or divalent cations (e.g., $\mathrm{K}^{+}, \mathrm{Ca}^{2+}$ ) across cellular membranes, thereby disrupting normal physiological intracellular ion concentrations [18-20]. Several in vitro studies have confirmed cytotoxicity of both compounds in the micromolar range [21-26]. These report that enniatin- and beauvericin-induced cell death is primarily based on apoptosis induction via the mitochondrial pathway $[22,27,28]$ or necrosis-induction via lysosomal damage [29-31]. Contrasting reports have been made regarding enniatin- and beauvericin-induced oxidative stress [32-34]. Furthermore, both compounds inhibit the activity of acyl-CoA:cholesterol acyltransferase (ACAT), a protein of the endoplasmic reticulum, which produces cholesteryl esters from cholesterol. The relationship between the ionophoric activity of beauvericin and enniatins and the degree of ACAT inhibition is however still unclear [35]. Studies focusing on in vivo effects of enniatins and beauvericin [36-42], have confirmed a low degree of toxicity. In the only study to report toxic effects of enniatins, the intraperitoneal (i.p.) administration of $10-40 \mathrm{mg} / \mathrm{kg}$ body weight (BW) every $8 \mathrm{~h}$ was lethal for immune-deficient mice within 2-5 days. Lower concentrations only caused weight loss [43]. Nevertheless, due to observed contamination levels, further studies are required to investigate chronic toxicity of both compounds, as well as 
potential combinatory effects due to the high co-occurrence with regulated mycotoxins. In their scientific opinion, the EFSA concluded in 2014 that acute exposure to enniatin and beauvericin is not a concern to human health. However, they further state that due to the lack of relevant in vivo toxicity data, no conclusion can be drawn about the effects of chronic exposure [17].

Similar problems-namely limited toxicity data-also apply to a large amount of other Fusarium-derived metabolites, found in cereal and cereal-based products. For example, according to Streit et al. [8], the cyclic histone deacetylate (HDAC) inhibitor apicidin [44-46] occured in $66 \%$ of analyzed samples $(n=83)$, with median and maximum concentrations of $1.9 \mu \mathrm{g} / \mathrm{kg}$ and $160 \mu \mathrm{g} / \mathrm{kg}$, respectively. Apicidin alters the acetylation status of histone and non-histone proteins. This leads to chromatin remodeling and epigenetic modification of gene expression, metabolic enzymes and transcription factors $[47,48]$. Aside from antiproliferative, cyto-differentiation and cytotoxic activity in mammalian cells [44,49,50], apicidin induces toxic effects in rats, including body weight loss, hemorrhage in the stomach, intestines and bladder and finally death [51].

Even less is known about aurofusarin and its related orange-brown polyketide rubrofusarin, which occur in $84 \%$ and $4 \%$ of analyzed samples $(n=83)$, respectively. Median and maximum concentrations were reported to be $85 \mu \mathrm{g} / \mathrm{kg}$ and $17,659 \mu \mathrm{g} / \mathrm{kg}$ for aurofusarin and $2374 \mu \mathrm{g} / \mathrm{kg}$ and $4923 \mu \mathrm{g} / \mathrm{kg}$ for rubrofusarin, respectively. The first characterization of aurofusarin cytotoxicity has only been made recently, showing pronounced effects in Caco-2 cells at $10 \mu \mathrm{M}$ [52]. With respect to in vivo effects, Dvorska et al. $[53,54]$ reported that the inclusion of aurofusarin in the maternal diet alters antioxidant composition and the fatty acid profile of quail eggs. The same authors reported a deterioration of chicken meat quality through the reduction of fat and protein content [55]. Few studies have investigated the effects of its related metabolite rubrofusarin. These describe rubrofusarin-induced inhibition of human DNA topoisomerase II- $\alpha$ [56] as well as antibiotic effects [40]. Equally little is known about the metabolites equisetin and bikaverin, which occur in $87 \%$ and $17 \%$ of feed samples $(n=83)$, respectively [8]. Median and maximum concentrations have been reported to reach $23 \mu \mathrm{g} / \mathrm{kg}$ and $13,680 \mu \mathrm{g} / \mathrm{kg}$ for equisetin, and $27,510 \mu \mathrm{g} / \mathrm{kg}$ and $51,130 \mu \mathrm{g} / \mathrm{kg}$ for bikaverin, respectively. Equisetin possesses weak activity against gram-positive bacteria [57], while bikaverin affects different biological processes [58-60] by exhibiting inhibitory activity against mammalian cell lines.

Slightly more is known about the metabolite moniliformin, which, according to Streit et al. [8], occurs in $76 \%$ of samples $(n=83)$ of feed and feed raw materials, with median and maximum concentrations of $45 \mu \mathrm{g} / \mathrm{kg}$ and $12,236 \mu \mathrm{g} / \mathrm{kg}$, respectively. Studies report damaging effects on energy metabolism through impairment of the pyruvate dehydrogenase enzyme complex and subsequent inhibition of the Krebs cycle and cellular respiration [61]. While the in vitro cytotoxic potential of moniliformin depends on the cell line it is applied to [62-64], contrasting reports have been made regarding whether [65] or not [66,67] moniliformin possesses genotoxic potential. In vivo studies of moniliformin report far more severe effects than those observed in vitro. Toxic effects have been observed in 1-day-old cockerels (oral) [68], in 9-month-old mink (i.p.) [69], in 7-week female broiler chickens (intravenous (i.v.)) [70], in male and female mice (i.p.) [71], in 7-day-old ducklings (oral) [72] and in female and male rats (oral) [72]. Furthermore, in vivo trials revealed damages to the heart muscle [69,72-74], muscular weakness and respiratory distress [72,73], reduced feed intake and weight gain $[70,74]$, as well as impaired immune function $[73,75]$.

Despite the natural co-occurrence of food- and feed-borne mycotoxins, the complexity of combination studies frequently leads to the establishment of legal limits, based on single compound studies. For instance, Commission Regulation (EC) 1881/2006 and its amendments regulating maximum levels for certain food contaminants, including fusariotoxins, are based on the assumption that these are present as individual compounds only [76]. However, the above described emerging metabolites are frequently co-produced with well-known fusariotoxins, such as DON [77]. For example, beauvericin and enniatins frequently co-occur with other Fusarium derived metabolites in grains and food products. These include culmorin, DON and derivatives, equisetin, fumonisins, fusaproliferin, fusaric acid, fusareon- $X$, moniliformin, monocerin, nivalenol, T-2/HT-2 toxins and zearalenone and 
its derivatives [8,78-86]. Furthermore, in their analysis of 83 samples of feed and feed raw materials using a multi mycotoxin LC-MS/MS method, Streit et al. [8], reported the co-occurrence of 69 different mycotoxins. According to the authors, mixtures of Fusarium toxins are detected frequently. In an analysis of the co-occurrence of regulated, masked and emerging mycotoxins, Kovalsky et al. [6], similarly concluded that the co-occurrence of regulated toxins such as DON was frequent with emerging toxins, such as for example enniatins and moniliformin. According to the EFSA database, DON, DON-3-glucoside, nivalenol, beauvericin and enniatins A, A1, B and B1 were measured in 70 samples of wheat grains of undefined end-use. Enniatin B and B1 were quantified in more than $50 \%$ of the data. The prevalence of for enniatin A, A1, beauvericin, nivalenol, DON, and DON-3-glucoside was $1 \%, 19 \%, 13 \%, 4 \%, 21 \%$ and $3 \%$, respectively [17]. Thus, natural co-occurrence of these and other mycotoxins not only implies the need for better knowledge and assessment of their individual toxicology, but highlights the importance of clarifying potential interactions.

Therefore, we investigated-for the first time-the influence of several fusariotoxins, which frequently co-occur with DON, on the intestinal epithelial integrity of differentiated IPEC-J2. Furthermore, aside from the effects of single fungal metabolites, we examined their influence on intestinal barrier function when combined with an otherwise no-effect concentration of DON. The study delivers valuable information regarding the effect these emerging toxins on a crucial toxicological target, the intestinal epithelium.

\section{Results}

\subsection{Deoxynivalenol}

We recently demonstrated that DON does not significantly decrease TEER of differentiated IPEC-J2 at concentrations below $5 \mu \mathrm{M}$ [87]. EC90 values of DON were equal to $8.08 \pm 3.15 \mu \mathrm{M}$ after $24 \mathrm{~h}, 4.53 \pm 0.85 \mu \mathrm{M}$ after $48 \mathrm{~h}$ and $4.45 \pm 1.37 \mu \mathrm{M}$ after $72 \mathrm{~h}$ of incubation. The highest concentration used during the present study, i.e., $3 \mu \mathrm{M}$, was therefore far below the EC90 of DON after 24, 48 and $72 \mathrm{~h}$.

\subsection{Enniatins and Combinations of Enniatins}

Effects of enniatin A, A1, B and B1 on TEER and viability of IPEC-J2 were investigated over $72 \mathrm{~h}$ (Figure 1a-d). Exposure of IPEC-J2 to $2.5 \mu \mathrm{M}$ enniatin A for $72 \mathrm{~h}$ had no effect on TEER. At $5 \mu \mathrm{M}$, enniatin A had no effect after 24 and $48 \mathrm{~h}$, but significantly reduced TEER by approximately $70 \%$ after $72 \mathrm{~h}(p=0.000)$. Enniatin A1 did not reduce TEER at $5 \mu \mathrm{M}$, showing effects only at $10 \mu \mathrm{M}$ after $24 \mathrm{~h}(-29 \%, p=0.032), 48 \mathrm{~h}(-64 \%, p=0.003)$ and $72 \mathrm{~h}(-74 \%, p=0.009)$. Treatment of IPEC-J2 with enniatin $B(1.5,2.5$, and $5 \mu \mathrm{M})$ did not affect TEER after $24 \mathrm{~h}$, but significantly reduced TEER at 2.5 and $5 \mu \mathrm{M}$ after $48 \mathrm{~h}$ (both $-55 \%, p=0.002$ ) and $72 \mathrm{~h}$ (both $-68 \%, p=0.000$ ). Enniatin B1 did not reduce TEER at $2.5 \mu \mathrm{M}$ over $72 \mathrm{~h}$, however induced significant decreases at $5 \mu \mathrm{M}$ after $48 \mathrm{~h}(-44 \%, p=0.007)$ and $72 \mathrm{~h}(-58 \%, p=0.001)$. Enniatin B had the strongest effect on TEER, followed by enniatin B1, A and A1.

We next assessed the effect of a combination of enniatins A, A1, B and B1 on TEER of IPEC-J2 in the absence (Figure 1e) or presence of DON (Figure 1f). A combination of all enniatins, containing $1.5 \mu \mathrm{M}$ or $3 \mu \mathrm{M}$ of each individual toxin, led to significant TEER decreases after $24 \mathrm{~h}(1.5 \mu \mathrm{M}:-30 \%$, $p=0.008 ; 3 \mu \mathrm{M}:-33 \%, p=0.000), 48 \mathrm{~h}(1.5 \mu \mathrm{M}:-64 \%, p=0.000 ; 3 \mu \mathrm{M}: 72 \%, p=0.000)$ and $72 \mathrm{~h}(1.5 \mu \mathrm{M}:$ $-75 \%, p=0.000 ; 3 \mu \mathrm{M}:-82 \%, p=0.000)$. The combination of enniatins, which if applied individually show no effect on TEER, seem to have an additive effect if applied as a combination. Addition of DON to the enniatin combinations did not further substantiate enniatin-induced TEER decreases. The combination of all enniatins and DON, with each toxin present at 1.5 or $3 \mu \mathrm{M}$, significantly reduced TEER after $24 \mathrm{~h}(1.5 \mu \mathrm{M}:-33 \%, p=0.001 ; 3 \mu \mathrm{M}:-41 \%, p=0.000), 48 \mathrm{~h}(1.5 \mu \mathrm{M}:-69 \%, p=0.000 ; 3 \mu \mathrm{M}$ : $-75 \%, p=0.003)$, and $72 \mathrm{~h}(1.5 \mu \mathrm{M}:-80 \%, p=0.000 ; 3 \mu \mathrm{M}:-83 \%, p=0.000)$.

To exclude that TEER reductions were due to cytotoxic effects, a neutral red (NR) assay was conducted after the final TEER measurement $(72 \mathrm{~h}$ ) (Figure 1a-f). Viability of IPEC-J2 treated 
with individual enniatins or with combinations of enniatins (+/ - DON) was unaffected at all test concentrations.

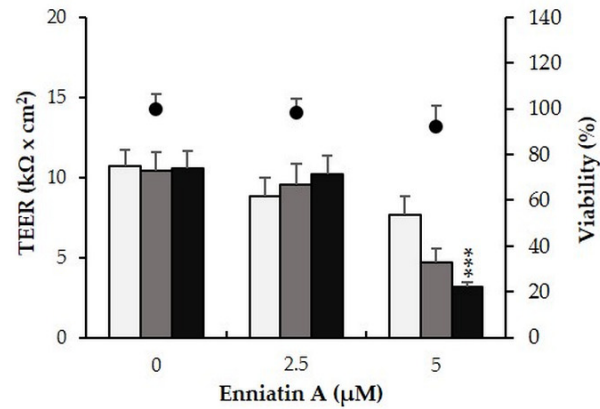

(a)

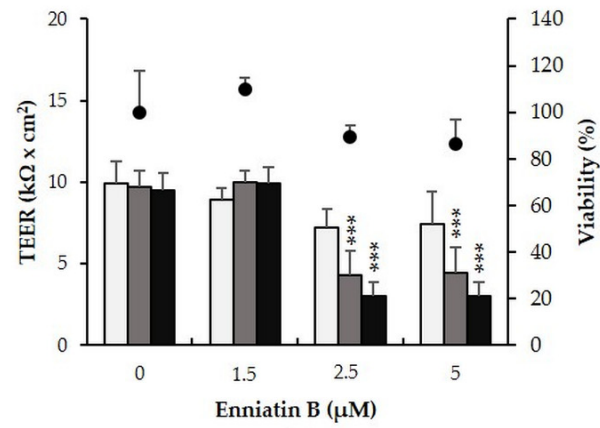

(c)

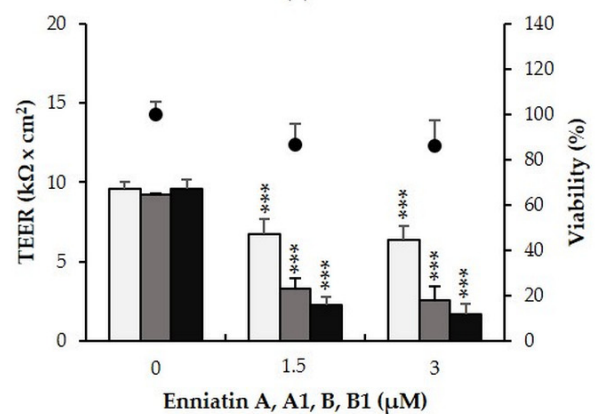

(e)

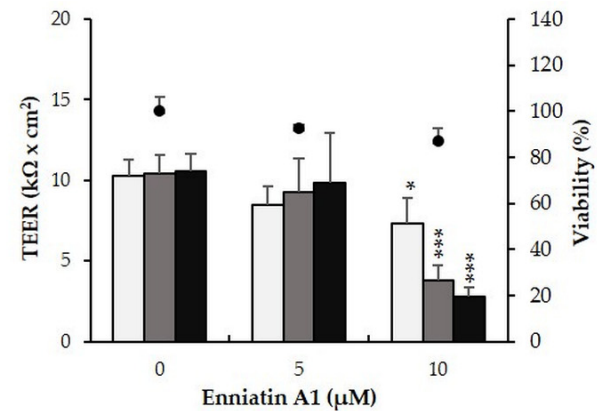

(b)

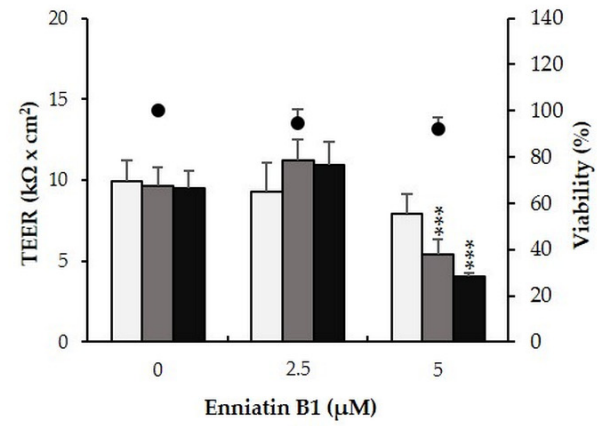

(d)

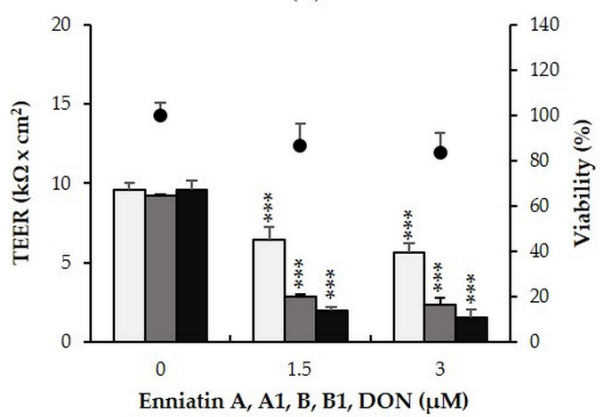

(f)

Figure 1. Effect of enniatin A, A1, B and B1 as well as combinations of enniatins (+/ - deoxynivalenol, DON) on transepithelial electrical resistance (TEER) and viability of differentiated intestinal porcine epithelial cells (IPEC-J2). IPEC-J2 were treated with (a) enniatin A (2.5 and $5 \mu \mathrm{M})$; (b) A1 (5 and $10 \mu \mathrm{M})$; (c) B (1.5, 2.5 and $5 \mu \mathrm{M})$; or (d) B1 $(2.5$ and $5 \mu \mathrm{M})$; as well as (e) a combination of all enniatins (each toxin: 1.5 or $3 \mu \mathrm{M}$ ); and (f) a combination of all enniatins with DON (each toxin: 1.5 or $3 \mu \mathrm{M}$ ). TEER was measured after 24, 48 and $72 \mathrm{~h}$. After the final TEER measurement, viability was determined via the neutral red (NR) assay. Asterisks indicate significant differences compared to control of the respective time point $\left({ }^{*} p<0.05, * * p<0.01, * * * p<0.001\right)$. Data represent mean $\pm \mathrm{SD}, n=3$.

\subsection{Beauvericin}

We next assessed the effect of beauvericin (1.5-10 $\mu \mathrm{M})$ on barrier integrity of IPEC-J2 (Figure 2a). While 1.5 and $3 \mu \mathrm{M}$ beauvericin had no effect on IPEC-J2, 5 and $10 \mu \mathrm{M}$ significantly reduced TEER after 24, 48 and $72 \mathrm{~h}$. Maximum TEER reductions were observed at $10 \mu \mathrm{M}$ beauvericin, with reductions of $59 \%$ after $24 \mathrm{~h}(p=0.000), 74 \%$ after $48 \mathrm{~h}(p=0.000)$ and $80 \%$ after $72 \mathrm{~h}(p=0.000)$. Combination of a no-effect beauvericin concentration $(2.5 \mu \mathrm{M})$ with $1.5 \mu \mathrm{M}$ or $3 \mu \mathrm{M}$ DON, did not lead to a significant reduction of TEER (Figure $2 b$ ). In all cases, viability was not significantly reduced at any concentration. 


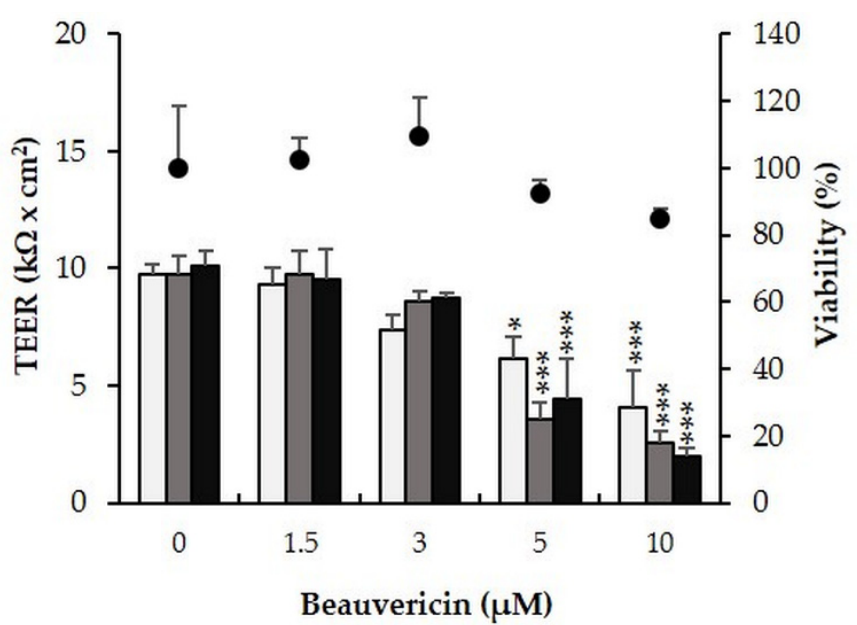

(a)

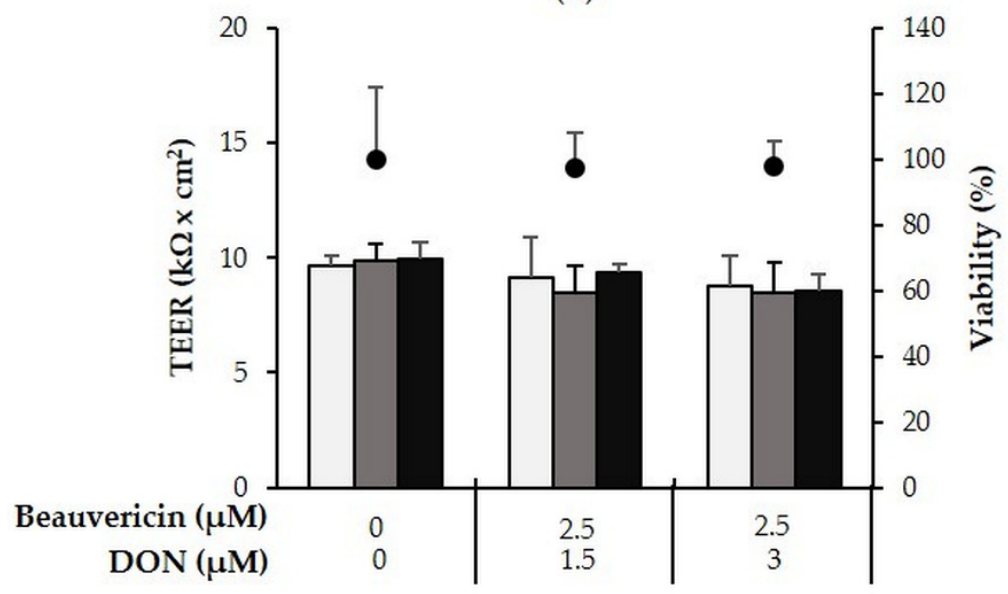

(b)

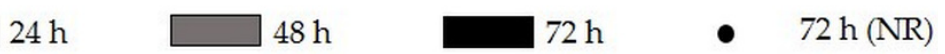

Figure 2. Effect of beauvericin (+/ - DON) on TEER and viability of differentiated intestinal porcine epithelial cells (IPEC)-J2. IPEC-J2 were treated with (a) beauvericin (1.5-10 $\mu \mathrm{M})$ as well as (b) a combination of beauvericin $(2.5 \mu \mathrm{M})$ and DON $(1.5$ or $3 \mu \mathrm{M})$. TEER was measured after 24,48 and $72 \mathrm{~h}$. After the final TEER measurement, viability was determined via the NR assay. Asterisks indicate significant differences compared to control of the respective time point ${ }^{*} p<0.05,{ }^{* *} p<0.01$, *** $p<0.001)$. Data represent mean $\pm \mathrm{SD}, n=3$.

\subsection{Apicidin}

Examination of the effect of apicidin $(0.438-2.5 \mu \mathrm{M})$ (Figure 3a), showed that while $0.438 \mu \mathrm{M}$ left TEER unaffected, 0.875-2.5 induced a time- and dose-dependent TEER decrease. At the maximum tested concentration of $2.5 \mu \mathrm{M}$ apicidin, TEER was decreased by $93 \%(p=0.006)(24 \mathrm{~h}), 98 \%(p=0.000)$ $(48 \mathrm{~h})$ and $99 \%(p=0.008)(72 \mathrm{~h})$. The combination of a no-effect apicidin concentration $(0.438 \mu \mathrm{M})$ and DON $(1.5$ or $3 \mu \mathrm{M})$ significantly reduced TEER after 48 and $72 \mathrm{~h}$, showing an additive effect. The combination with $1.5 \mu \mathrm{M}$ DON reduced TEER by approximately $23 \%(p=0.013)$ after $48 \mathrm{~h}$ and $21 \%$ $(p=0.003)$ after $72 \mathrm{~h}$. The combination of $0.438 \mu \mathrm{M}$ apicidin with $3 \mu \mathrm{M}$ DON reduced TEER by $31 \%$ after $48 \mathrm{~h}(p=0.032)$ and $27 \%(p=0.009)$ after $72 \mathrm{~h}$ (Figure 3b).

Neither apicidin alone nor the combination of apicidin with DON reduced IPEC-J2 viability after $72 \mathrm{~h}$. 


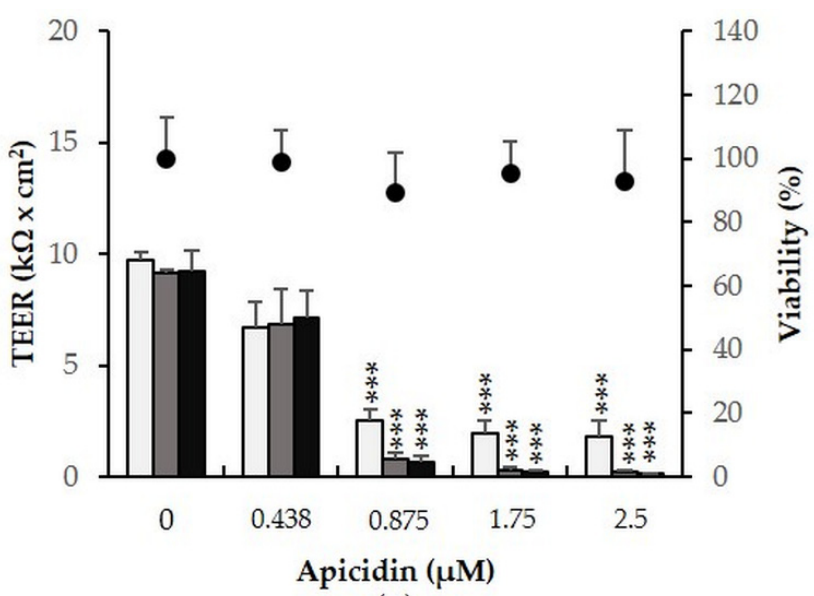

(a)

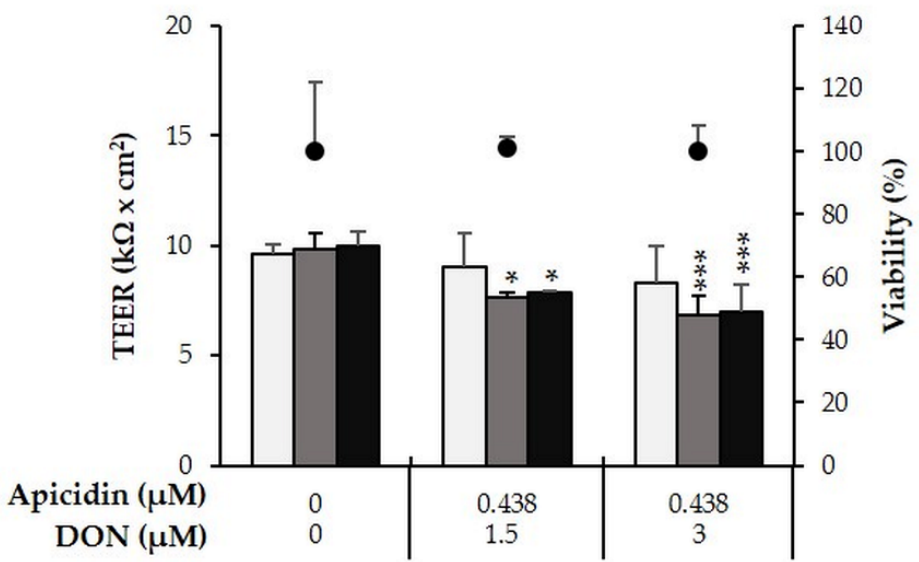

(b)

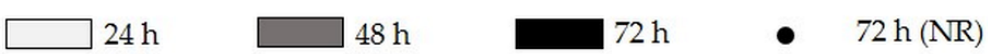

Figure 3. Effect of apicidin (+/ - DON) on TEER and viability of differentiated IPEC-J2. Differentiated IPEC-J2 were treated with (a) apicidin $(0.438-2.5 \mu \mathrm{M})$ or $(\mathbf{b})$ a combination of apicidin $(0.438 \mu \mathrm{M})$ and DON $(1.5$ or $3 \mu \mathrm{M})$. TEER was measured after 24,48 and $72 \mathrm{~h}$. After the final TEER measurement, viability was determined via the NR assay. Asterisks indicate significant differences compared to control of the respective time point $\left({ }^{*} p<0.05,{ }^{* *} p<0.01,{ }^{* * *} p<0.001\right)$. Data represent mean $\pm \mathrm{SD}, n=3$.

\subsection{Aurofusarin}

Exposure to $5 \mu \mathrm{M}$ aurofusarin did not affect TEER of IPEC-J2 over $72 \mathrm{~h}$. At $10 \mu \mathrm{M}$, aurofusarin significantly reduced TEER after $24 \mathrm{~h}(-30 \%, p=0.019), 48 \mathrm{~h}(-68 \%, p=0.001)$ and $72 \mathrm{~h}(-83 \%$, $p=0.000$ ) (Figure $4 \mathrm{a})$. When combined with DON (1.5 or $3 \mu \mathrm{M})$, TEER of IPEC-J2 was significantly decreased after 24 and $48 \mathrm{~h}$. The combination of an otherwise no-effect aurofusarin concentration $(5 \mu \mathrm{M})$ with DON $(1.5 \mu \mathrm{M})$ significantly reduced TEER by $15 \%(p=0.013)$ after $24 \mathrm{~h}$ and by $25 \%$ $(p=0.002)$ after $48 \mathrm{~h}$. Aurofusarin $(5 \mu \mathrm{M})$ combined with $3 \mu \mathrm{M}$ DON reduced TEER by $20 \%$ after $24 \mathrm{~h}$ $(p=0.000)$ and by $32 \%(p=0.001)$ after $48 \mathrm{~h}$ (Figure $4 \mathrm{~b})$. The combination of aurofusarin and DON therefore seems to have an additive effect. No significant effects were observed after $72 \mathrm{~h}$. In all cases, viability of IPEC-J2 remained unaffected. 


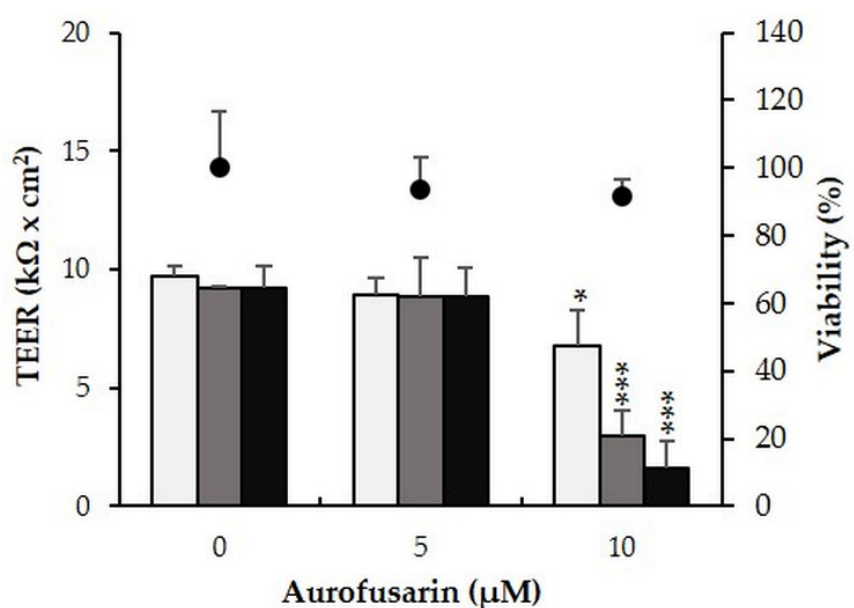

(a)

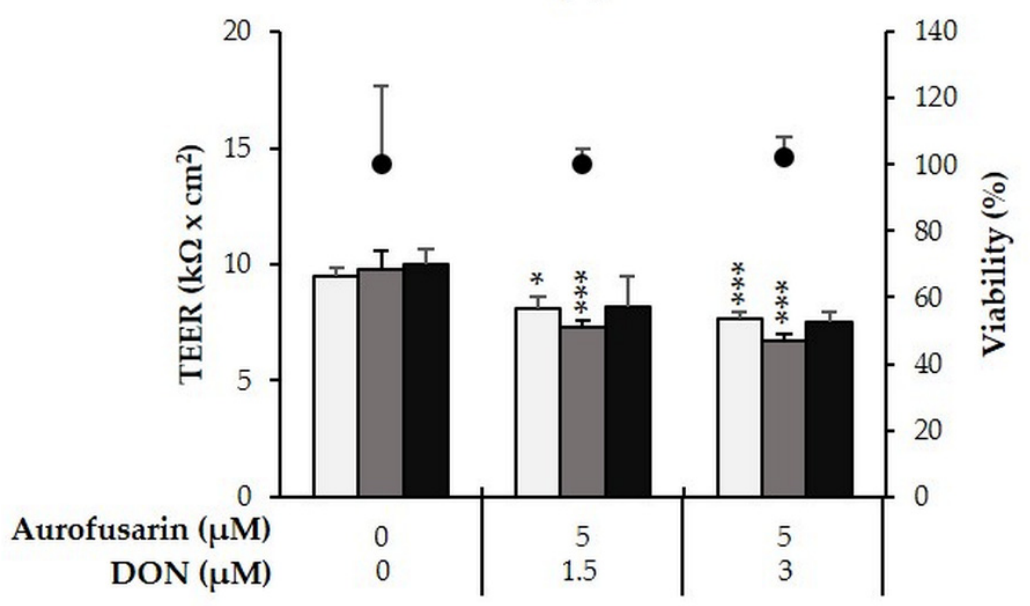

(b)

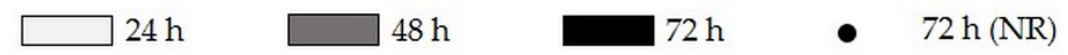

Figure 4. Effect of aurofusarin (+/ - DON) on TEER and viability of differentiated IPEC-J2. IPEC-J2 were treated with $(\mathbf{a})$ aurofusarin $(5-10 \mu \mathrm{M})$ as well as $(\mathbf{b})$ a combination of aurofusarin $(5 \mu \mathrm{M})$ with DON $(1.5$ or $3 \mu \mathrm{M})$. TEER was measured after 24,48 and $72 \mathrm{~h}$. After the final TEER measurement, viability was determined via the NR assay. Asterisks indicate significant differences compared to control of the respective time point $\left({ }^{*} p<0.05,{ }^{* *} p<0.01,{ }^{* * *} p<0.001\right)$. Data represent mean $\pm \mathrm{SD}, n=3$.

\subsection{Metabolites with No Effect on TEER}

Exposure of IPEC-J2 to moniliformin, equisetin, bikaverin and rubrofusarin (all: 5 and $10 \mu \mathrm{M}$ ) did not affect TEER or viability over a time period of $72 \mathrm{~h}$ (Figure 5a-d). 


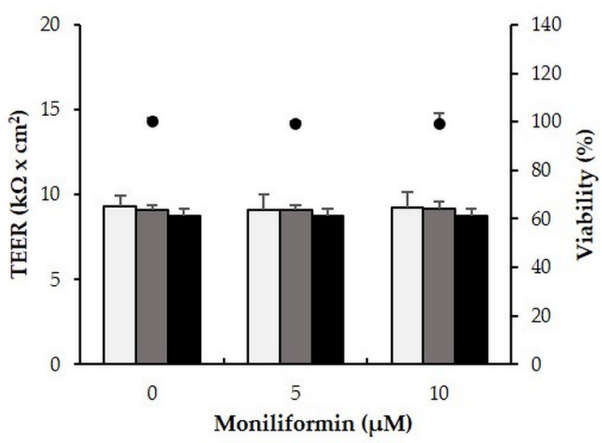

(a)

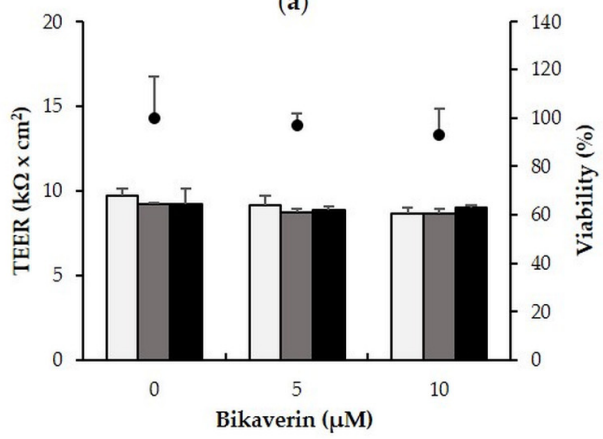

(c)

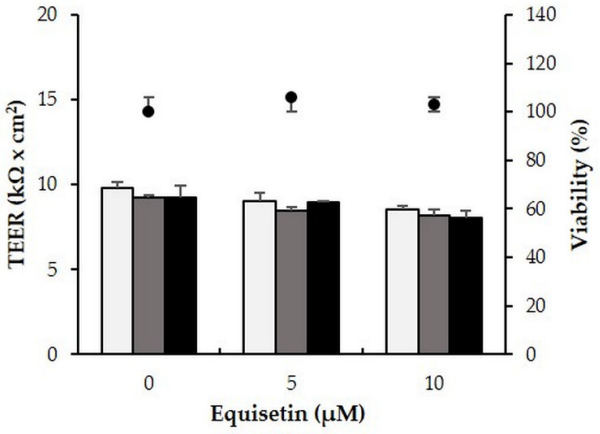

(b)

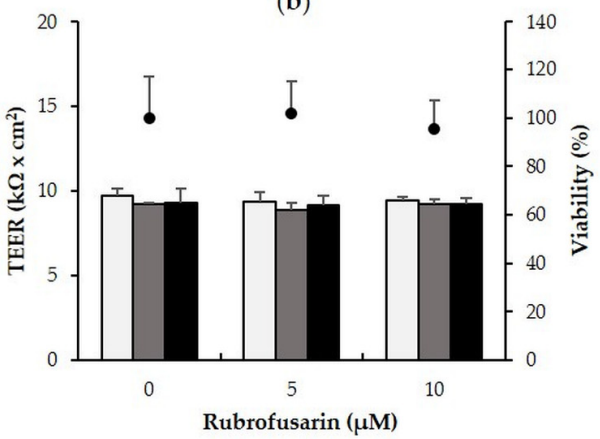

(d)
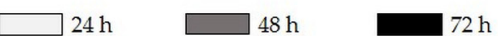

- $\quad 72 \mathrm{~h}(\mathrm{NR})$

Figure 5. Effect of moniliformin, equisetin, bikaverin and rubrofusarin on TEER and viability of differentiated IPEC-J2. IPEC-J2 were treated with (a) moniliformin $(5-10 \mu \mathrm{M})$; (b) equisetin $(5-10 \mu \mathrm{M})$; (c) bikaverin $(5-10 \mu \mathrm{M})$; and (d) rubrofusarin (5-10 $\mu \mathrm{M})$. TEER was measured after 24, 48 and $72 \mathrm{~h}$. Following the final TEER measurement, viability was determined via the NR assay. Data represent mean $\pm \mathrm{SD}, n=3$.

\section{Discussion}

Advanced analytical methods have enabled the discovery of numerous new Fusarium-metabolites, most of which have received little to no investigatory attention. In particular, their effect on the intestinal barrier function has so far been neglected. Thus, we herein present the first investigation of the effect of such metabolites on intestinal barrier integrity of intestinal porcine epithelial cells. Such effects are well documented for the trichothecene mycotoxin DON [11,15,87-89], as well as for aflatoxins [90,91], zearalenone [92,93], ochratoxin A [94,95], patulin [96,97], fumonisin B1 [98-100] and T2 toxin [16,101]. Similarities with the original in vivo cell tissue and with humans and the fact that pigs are the most susceptible species to Fusarium mycotoxin DON, make porcine cell lines a highly suitable option for in vitro analysis of intestinal barrier integrity [102]. IPEC-J2 [103], possess strong morphological and functional resemblance of intestinal epithelial cells in vivo and have recently been reported morphologically and functionally even more differentiated than its related cell line IPEC-1 [104].

With respect to enniatins, the use of the IPEC-J2 cell line, isolated from the jejunum of neonatal piglets, is of particular significance. In an analysis of the distribution of enniatins in different rat tissues, Rodriguez-Carasco et al. [36] and Manyes et al. [38] reported the highest levels of the compounds in the jejunum, liver and fat tissue, concluding that the jejunum is a significant site of enniatin absorption. The enniatins investigated in this study were chosen due to their natural occurrence in food and feed. In numerous European countries, contamination levels range from $\mu \mathrm{g} / \mathrm{kg}$ to $\mathrm{mg} / \mathrm{kg}$ in cereal grains and unprocessed food. According to Malachova et al. [82], 73\% of cereal-based products in the Czech Republic were contaminated with enniatins A, A1, B and B1. In the remaining samples, at least three of the four mycotoxins were identified. Furthermore, $89 \%$ of Finish grain samples were co-contaminated 
with enniatins A, A1, B and B1, of which enniatin B and B1 occurred most frequently in commercial samples [80]. In Spain, up to $82 \%$ of available cereal products are co-contaminated by enniatins [105]. Enniatins are not legislated-no estimated daily intake (TDI) or provisional maximum tolerable daily intake (PMTDI) has been proposed by authorities. The choice of realistic in vitro concentrations is therefore difficult. Concentrations of enniatins used for this study were based on an approach by Prosperini et al. [106], who concluded that for other fusariotoxins such as fumonisins, the maximum levels in raw cereals reach approximately $2000 \mu \mathrm{g} / \mathrm{kg}$. Taking this value into consideration and considering cereal consumption in the European Union to be $125.4 \mathrm{~kg}$ /year, the group estimated that Europeans consumed approximately $680 \mu \mathrm{g}$ fumonisins per day, and applied this calculation to enniatins, for example enniatin A1. Following this approach, ingestion levels were estimated to approximately equal $1.01 \mu \mathrm{M}$ in vitro. In addition, it is known that enniatins are particularly stable in the gastrointestinal tract [27], suggesting accumulation of the metabolites. Considering this and the fact that enniatin concentrations in food additionally depend on dietary food variety, we applied enniatin concentrations ranging up to $10 \mu \mathrm{M}$.

While all tested enniatins reduced TEER of differentiated IPEC-J2 in the micromolar range, sensitivities to the toxins varied. IPEC-J2 were most sensitive to enniatin $B$, followed by enniatin B1, A and A1. To date, no other reports exist regarding the effect of enniatins on TEER. However, the negative effect, as observed in this study, could inherently be related to the typical ionophoric properties of enniatins, which facilitate the transport of mono- or divalent cations such as $\mathrm{K}^{+}$or $\mathrm{Ca}^{2+}$ across membranes. According to Tai et al. [107], an increase in intracellular $\mathrm{Ca}^{2+}$ through the ionophore A23187, decreased tight junction (TJ) resistance in T84 monolayers. Authors speculate that this intracellular $\mathrm{Ca}^{2+}$ effect was mediated by protein kinase C. Similarly, Kan et al. [108], demonstrated that increases of intracellular $\mathrm{Ca}^{2+}$ via the ionophore A23187, significantly increases TJ permeability in rat liver.

A comparable explanation could apply to beauvericin, which reduced TEER of differentiated IPEC-J2 at 5 and $10 \mu \mathrm{M}$ after 24, 48 and $72 \mathrm{~h}$. The choice of a suitable beauvericin concentration was based on previous in vitro studies, which report that, like enniatins, beauvericin elicits its toxicity via ionophoric properties in the low micromolar range [21-23,25]. It has recently been reported, that beauvericin ( 3 and $10 \mu \mathrm{M}$ ) induces expression of phosphorylated mitogen activated protein kinase (MAPK) ERK44/42 within $24 \mathrm{~h}$ of exposure [109]. This is a documented feature of DON, where impairments of barrier function-shown by TEER decreases and compromised expression of TJ proteins claudin-3 and 4-are mediated through p44/42 phosphorylation [13,87]. It seems plausible that a potential beauvericin-induced activation of $\mathrm{p} 44 / 42$ could at least partially be responsible for the observed reductions of TEER in beauvericin-treated IPEC-J2.

Negative effects on TEER were also observed by the metabolites apicidin and aurofusarin. Few in vitro cell-based studies are dedicated to these metabolites. Han et al. [110] for example, tested the effect of apicidin on cell proliferation of diverse cell lines via the sulforhodamine B assay and reported IC50 concentrations ranging between approximately $160 \mathrm{nM}$ and $3.8 \mu \mathrm{M}$. Furthermore, Bauden et al., [44] reported cytotoxicity of apicidin in pancreatic cancer cells at $100 \mathrm{nM}$ after $48 \mathrm{~h}$. Consequently, apicidin was applied to differentiated IPEC-J2 at low concentrations ranging between 0.438 to $2.5 \mu \mathrm{M}$. Profound TEER-reducing effects of apicidin were already observed at $0.875 \mu \mathrm{M}$ after 24, 48 and $72 \mathrm{~h}$. Apicidin-induced TEER reductions are particularly interesting with respect to its ability to inhibit HDAC and recent reports made by Krishnan et al. [111]. Authors of this study reported that sodium butyrate and trichostatin A, two structurally different HDAC inhibitors, significantly inhibited the expression of TJ protein claudin-1 in colon cancer cells, seemingly through the modulation of claudin-1 mRNA stability. Although no studies have investigated the effect of apicidin on TJ expression, its properties as a HDAC inhibitor could contribute to its negative effect on TEER, an inherent measure of TJ intactness. Analysis of aurofusarin and its related orange-brown polyketide rubrofusarin on TEER of IPEC-J2 revealed negative effects of aurofusarin, not however of rubrofusarin. Little is known regarding the toxicology of these compounds. Based on a recent study of aurofusarin, which revealed 
strong cytotoxic effects at $10 \mu \mathrm{M}$ in Caco-2 cells [52], both metabolites were applied to cells up to a concentration of $10 \mu \mathrm{M}$. In accordance with the latter study, we first report aurofusarin-induced TEER reductions at $10 \mu \mathrm{M}$ at all three time points. Interestingly, Dvosrka et al. [53,54,112], reported that the inclusion of aurofusarin in the maternal diet induces changes in antioxidant composition and fatty acid profile of quail eggs. Thus, one could speculate that possibly the lipid bilayer of the cell membrane, in particular its phospholipids, could pose as a toxicological target of aurofusarin. Membrane defects could in turn negatively affect measured TEER values.

We furthermore report that the metabolites moniliformin, equisetin and bikaverin do not negatively affect TEER of differentiated IPEC-J2. The lack of a negative in vitro effect of moniliformin is in accordance with observations reported in literature. Although numerous in vivo studies have revealed severe effects of moniliformin in diverse species $[68,70,75]$, in vitro effects have been described as mild [62,113]. It has been suggested that the incomplete uptake of the polar toxin through the cell membrane in cell cultures studies may be a possible explanation for this discrepancy.

Although the investigation of their individual effects is significant and an important prerequisite, the natural co-contamination of Fusarium-derived metabolites in food and feed [2,8], additionally calls for the evaluation of combined effects. In fact, mycotoxins of similar structure or those produced by the same species or families, are likely to exhibit a similar mode of action and may therefore exert additive effects [114]. Enniatins, for example, most frequently occur in combinations. We therefore treated IPEC-J2 with a mixture of enniatins A, A1, B and B1, with each toxin being present at $1.5 \mu \mathrm{M}$ and $3 \mu \mathrm{M}$, i.e., no-effect concentration if applied individually. These combinations led to highly significant reductions of TEER after 24, 48 and $72 \mathrm{~h}$, pointing towards an additive effect. This is in accordance with Prosperini et al. [106], who tested a quaternary mixture of enniatin A, A1, B and B1 on viability of Caco- 2 cells, with each toxin applied at $0.3125,0.75,1.25$, or $2.5 \mu \mathrm{M}$. Authors concluded a general additive effect.

Furthermore, enniatins as well as other Fusarium-derived metabolites frequently co-occur with other primary mycotoxins, such as DON [6]. We recently reported that DON concentrations below $5 \mu \mathrm{M}$ do not negatively affect TEER of differentiated IPEC-J2 over a duration of $72 \mathrm{~h}$ [87]. Therefore we combined no-effect concentrations of metabolites (if applied individually) with no-effect DON concentrations $(1.5$ and $3 \mu \mathrm{M})$. With regard to enniatins, this did not additionally increase the effect of the enniatin mixture on TEER of IPEC-J2. Similarly, the combination of a no-effect beauvericin concentration with a no-effect DON concentration, left TEER of differentiated IPEC-J2 unaffected. Only one study, focusing on DNA fragmentation in Caco-2 cells, reported additivity of beauvericin and DON. In the same study authors additionally reported synergistic effects with regard to lipid peroxidation [115]. Ficheux et al. [62] observed synergism between beauvericin and DON in terms of cytotoxicity in human hematopoietic progenitors. Finally, Ruiz et al. [116,117] identified antagonistic cytotoxic effects of beauvericin and DON in Chinese hamster ovary and monkey kidney epithelial cells. With respect to apicidin and aurofusarin, we found that the combination of a no-effect apicidin concentration with DON, as well as a no-effect aurofusarin concentration with DON, led to significant TEER reductions. This hints at an additive interaction and raises the significance of these toxins due to their natural co-occurrence. In this context, we certainly acknowledge the limitation of our study with regard to being able to draw firm conclusions about combinatory effects. We are aware that to able to firmly conclude additive, synergistic or antagonistic effects, it is necessary to conduct an analysis according to the isobologram method of Chou [118] and Chou and Talalay [119]. Nevertheless, we provide a first insight into potential comminatory effects of these metabolites, especially with regard to their interaction with DON and highlight the need for further investigation into this direction.

Despite the effects observed on TEER, viability of IPEC-J2 remained unaffected throughout all experiments. None of the tested metabolites, whether they reduced TEER or not, negatively affected IPEC-J2 viability. Thus, it can be concluded, that TEER reductions were not a result of cell death. Although, for all tested metabolites of this study, we are the first to report viability data in differentiated IPEC-J2, cytotoxicity of several metabolites has been studied in alternative cell models. With respect 
to enniatins and beauvericin, studies repeatedly report cytotoxicity at micromolar concentrations in diverse cell types [21-23,25,77]. Only few reports have been made regarding in vitro cytotoxicity of apicidin, with strong deviations depending on the cells used [49]. In accordance with our findings, in vitro investigations of moniliformin report a low degree of cytotoxicity [113,120]. Furthermore, only one study has shown cytotoxicity of $10 \mu \mathrm{M}$ aurofusarin in Caco-2 cells [53], which is in agreement with our finding. With regard to equisetin, rubrofusarin and bikaverin, no cytotoxicity reports are available.

\section{Conclusions}

Therefore, we present the very first analysis of the influence of several Fusarium-derived metabolites, which frequently co-occur with DON, on the intestinal epithelial barrier integrity of differentiated IPEC-J2. We demonstrated that while enniatins A, A1, B and B1, as well as beauvericin, apicidin, and aurofusarin severely reduced intestinal barrier integrity of differentiated IPEC-J2, other metabolites such as moniliformin, equisetin, rubrofusarin and bikaverin had no effect (apicidin $>$ enniatin B $>$ beauvericin $=$ DON $>$ enniatin B1 $>$ enniatin $\mathrm{A}>$ aurofusarin $=$ enniatin A1 $>$ moniliformin $=$ equisetin $=$ bikaverin $=$ rubrofusarin). We additionally provide-for the first time-cytotoxicity data of these metabolites in the intestinal porcine epithelial cells. Furthermore, aside from the effects of single mycotoxins, we provide insights into potential additive effects of enniatins, beauvericin, apicidin and aurofusarin with DON. The study substantially adds to the current knowledge of the toxicology of these so-called emerging toxins with respect to a crucial toxicological target, the intestinal epithelium. It presents an interesting starting point for further evaluations, for instance regarding effects of these metabolites on tight junctions or MAPK activity. In preliminary trials we were able to show that the selected metabolites-just like DON [87]—do not reduce protein expression of zona occludens (ZO)-1 and occludin. However, preliminary work suggests effects on the expression of tight junction protein, claudin-1 (data not shown). A similar effect was seen for DON in Springler et al. [87]. Further investigations into this direction are required. The collection of in vivo data of these compounds in pigs, especially in combination with the most common mycotoxin DON, presents an urgent need. Particularly their effect on intestinal structure and function is of great interest, since the so called "leaky gut" can be associated with a particularly high susceptibly to diseases as well as reduced growth performance.

\section{Materials and Methods}

\subsection{Cell Culture}

The non-transformed intestinal porcine epithelial cells IPEC-J2 (ACC 701; Leibnitz Institute DSMZ, German Collection of Microorganisms and Cell Cultures, Braunschweig, Germany) were continuously maintained in complete cultivation medium consisting of Dulbecco's modified eagle medium (DMEM/Ham's F12 (1:1), Biochrom AG, Berlin, Germany), supplemented with 5\% fetal bovine serum, $1 \%$ insulin-transferrin-selenium, $5 \mathrm{ng} / \mathrm{mL}$ epidermal growth factor, 2-5 mM Glutamax (all Gibco ${ }^{\mathrm{TM}}$, Life Technologies, Carlsbad, CA, USA) and $16 \mathrm{mM}$ 4-(2-hydroxyethyl)-1-piperazineethanesulfonic acid (Sigma-Aldrich, St. Louis, MO, USA) at $39{ }^{\circ} \mathrm{C}$ and $5 \% \mathrm{CO}_{2}$. Mycoplasma tests were performed regularly via PCR to confirm that cells were free of mycoplasma contamination (Venor $^{\circledR}$ GeM Mycoplasma Detection Kit; Minvera Biolabs GmbH, Berlin, Germany). Cells were routinely seeded at $1 \times 10^{6}$ cells $/ \mathrm{mL}$ in $150 \mathrm{~cm}^{2}$ tissue culture flasks (Eppendorf, Hamburg, Germany) with $28 \mathrm{~mL}$ complete cultivation medium and subcultured upon confluence every 4 days for a maximum of 15 passages. For assays, confluent cells were detached using Trypsin (0.25\%)-ethylenediaminetetraacetic acid (EDTA, $0.5 \mathrm{mM}$ ).

\subsection{Chemicals}

Deoxynivalenol (DON, from Fusarium sp., $\geq 95 \%$, Biopure, RomerLabs ${ }^{\circledR}$, Tulln, Austria), was dissolved in sterile distilled water to produce a stock concentration of $6.75 \mathrm{mM}$ and was further diluted 
to the desired working concentrations in complete cultivation medium. Enniatin A, A1, B and B1 (all from Gnomonia errabunda, $\geq 95 \%$ ), as well as moniliformin (from Fusarium proliferatum, $\geq 98 \%$ ), all from Sigma-Aldrich, St. Louis, MO, USA, and aurofusarin (from Fusarium graminearum, $\geq 97 \%$ ), equisetin (from Fusarium equiseti, $\geq 99 \%$ ) and bikaverin (from Fusarium sp., $\geq 95 \%$ ), all from Santa Cruz Biotechnology Inc., Dallas, TX, USA, were prepared in dimethyl sulfoxide (DMSO) as a stock solution of $1 \mathrm{mg} / \mathrm{mL}$. Beauvericin (from Beauveria sp., $\geq 97 \%$ ) and rubrofusarin (from Fusarium graminearum, $\geq 98 \%$ ), both from Adipogen International, Liestal, Switzerland, as well as apicidin (from Fusarium sp., $\geq 95 \%$, Santa Cruz Biotechnology Inc., Dallas, TX, USA) were prepared in DMSO as stock solution of $5 \mathrm{mg} / \mathrm{mL}$. Dilutions to the desired working concentrations were made in complete cultivation medium. DMSO concentrations ins sample dilutions did not exceed a concentration of $1 \%$. Effects of this DMSO concentration on experimental parameters were excluded (Figure S1).

\subsection{Measurement of Transepithelial Electrical Resistance (TEER)}

IPEC-J2 were seeded in the apical compartment of $1.12 \mathrm{~cm}^{2}$ Transwell ${ }^{\circledR}$ polyester membrane inserts with $0.4 \mu \mathrm{M}$ pores (Corning Inc., New York, NY, USA) at a seeding density of $1 \times 10^{5}$ cells /insert and differentiated for 8 days, as previously described by our group. Subsequently, cells were treated with either enniatin $\mathrm{A}(2.5$ and $5 \mu \mathrm{M}), \mathrm{A} 1(5$ and $10 \mu \mathrm{M}), \mathrm{B}(1.5,2.5$ and $5 \mu \mathrm{M}), \mathrm{B} 1(2.5$ and $5 \mu \mathrm{M})$, beauvericin $(1.5-10 \mu \mathrm{M})$, apicidin $(0.438-2.5 \mu \mathrm{M})$, aurofusarin, moniliformin, equisetin, bikaverin or rubrofusarin (all: 5 and $10 \mu \mathrm{M}$ ). Concentrations were based on available literature reports. Alternatively, metabolite combinations were tested, with each metabolite being present at a no-effect concentration if applied individually. Cells were treated with a combination of enniatins A, A1, B and B1 (each toxin: 1.5 or $3 \mu \mathrm{M}$ ), a combination of enniatins A, A1, B, B1 and DON (each toxin: 1.5 or $3 \mu \mathrm{M}$ ), a combination of apicidin $(0.438 \mu \mathrm{M})$ and DON $(1.5$ or $3 \mu \mathrm{M})$, a combination of aurofusarin $(5 \mu \mathrm{M})$ and DON $(1.5$ or $3 \mu \mathrm{M})$, and a combination of BEA $(2.5 \mu \mathrm{M})$ and DON $(1.5$ or $3 \mu \mathrm{M})$. Untreated cells served as negative control in each experiment. TEER was measured after 24, 48 and $72 \mathrm{~h}$, using a Millicell-Electrical Resistance System (ERS, Merck Millipore, Billerica, MA, USA). The unit area resistance was obtained by multiplying the meter reading $(\mathrm{Ohm})$ by the surface area of the Transwell ${ }^{\circledR}$ membrane $\left(1.12 \mathrm{~cm}^{2}\right)$. The resulting dimension was $\mathrm{Ohm} \times \mathrm{cm}^{2}$.

\subsection{Viability Assay}

After the final TEER measurement, viability of IPEC-J2 was examined via the neutral red (NR) assay (Aniara, West Chester, OH, USA). At the end of the 72-h incubation period, treatments were removed and cells were washed with a washing buffer provided by the assay kit. According to the manufacturer's instructions, NR was added to the negative control and test inserts at a final dilution of 1:100 in complete cultivation medium at $39{ }^{\circ} \mathrm{C}$ for $3 \mathrm{~h}$. Afterwards cells were fixed for $1 \mathrm{~min}$ with the provided fixing solution and incubated with the provided solubilization solution at room temperature for $15 \mathrm{~min}$. Next, $100 \mu \mathrm{L}$ of each insert was transferred to individual wells of a fresh 96-well plate (Eppendorf, Hamburg, Germany). The quantity of dye incorporated into cells was measured photometrically at $540 \mathrm{~nm}$, with a reference wavelength of $690 \mathrm{~nm}$, using a microplate reader (Biotek, Winoosky, VT, USA). The obtained optical density (OD) is directly proportional to the number of viable cells. Results were calculated as percent viability normalized to the negative control, which was set to $100 \%$.

\subsection{Statistical Analysis}

Statistical analysis was performed with IBM ${ }^{\circledR}$ SPSS Statistics (Version 19.0, IBM corp., New York, NY, USA, 2010). Values of each independent experiment were expressed as means of triplicates \pm standard deviation (SD) of three independent experiments. All values were analyzed for normality (Shapiro-Wilk) as well as homogeneity of variance (Levene Statistics). Normally distributed homogenous data were analyzed by analysis of variance (ANOVA) and subsequently via the Dunnett's 
$t$-test. If data were normally distributed but not homogenous, ANOVA and Dunnett's T3-test was used. If normal distribution was violated, the Kruskall-Wallis Test was used.

Supplementary Materials: The following are available online at www.mdpi.com/2072-6651/8/11/345/s1, Figure S1: Effect of DMSO (1\%) on TEER and viability of differentiated IPEC-J2. Differentiated IPEC-J2 were treated with DMSO (1\%). TEER was measured after 24, 48 and $72 \mathrm{~h}$. After the final TEER measurement, viability was determined via the NR assay. Data represent mean $\pm \mathrm{SD}, n=3$.

Acknowledgments: The authors would like to thank the Austrian Research Promotion Agency (FFG) for funding this study (grant number 848211).

Author Contributions: The experiments were conceived and designed by A.S., B.N., E.M., and G.S. The experiments were performed by G.-J.V. Analysis of data was performed by A.S., B.N., E.M., and G.-J.V. The paper was written by A.S., B.N. and E.M.

Conflicts of Interest: The authors declare no conflict of interest. The founding sponsors had no role in the design of the study; in the collection, analyses, or interpretation of data; in the writing of the manuscript and in the decision to publish the results.

\section{Abbreviations}

The following abbreviations are used in this manuscript:

$\begin{array}{ll}\text { ACAT } & \text { acyl-CoA:cholesterol acyltransferase } \\ \text { BW } & \text { body weight } \\ \text { DMEM } & \begin{array}{l}\text { Dulbecco's modified Eagle's medium } \\ \text { dimethyl sulfoxide } \\ \text { DMSO }\end{array} \\ \text { DON } & \text { deoxynivalenol } \\ \text { EFSA } & \text { European food safety authority } \\ \text { HDAC } & \text { histone deacetylase } \\ \text { i.p. } & \text { intraperitoneal } \\ \text { i.v. } & \text { intravenous } \\ \text { IPEC } & \text { intestinal porcine epithelial cells } \\ \text { LC-MS } & \text { liquid chromatography-mass spectrometry } \\ \text { MAPK } & \text { mitogen activated protein kinase } \\ \text { NR } & \text { neutral red } \\ \text { OD } & \text { optical density } \\ \text { TEER } & \text { transepithelial electrical resistance } \\ \text { TJ } & \text { tight junction }\end{array}$

\section{References}

1. Frisvad, J.C.; Thrane, U.; Samson, R.A.; Pitt, J.I. Important mycotoxins and the fungi which produce them. Adv. Exp. Med. Biol. 2006, 571, 3-31. [PubMed]

2. Streit, E.; Schatzmayr, G.; Tassis, P.; Tzika, E.; Marin, D.; Taranu, I.; Tabuc, C.; Nicolau, A.; Aprodu, I.; Puel, O.; et al. Current situation of mycotoxin contamination and co-occurrence in animal feed-Focus on Europe. Toxins (Basel) 2012, 4, 788-809. [CrossRef] [PubMed]

3. Berthiller, F.; Brera, C.; Crews, C.; Iha, M.H.; Krska, R.; Lattanzio, V.M.T.; MacDonald, S.; Malone, R.J.; Maragos, C.; Solfrizzo, M.; et al. Developments in mycotoxin analysis: An update for 2013-2014. World Mycotoxin J. 2015, 8, 5-35. [CrossRef]

4. Berthiller, F.; Brera, C.; Crews, C.; Iha, M.H.; Krska, R.; Lattanzio, V.M.T.; MacDonald, S.; Malone, R.J.; Maragos, C.; Solfrizzo, M.; et al. Developments in mycotoxin analysis: An update for 2014-2015. World Mycotoxin J. 2016, 9, 5-30. [CrossRef]

5. Sulyok, M.; Berthiller, F.; Krska, R.; Schumacher, R. Application of an LC-MS/MS based multi-mycotoxin method for the semi-quantitative determination of mycotoxins occurring in different types of food infected by moulds. Food Chem. 2010, 119, 408-416. [CrossRef]

6. Kovalsky, P.; Kos, G.; Nährer, K.; Schwab, C.; Jenkins, T.; Schatzmayr, G.; Sulyok, M.; Krska, R. Co-occurence of regulated, masked and emerging mycotoxins and secondary metabolites in finished feed and maize-A global review. Toxins 2016. Under review.

7. Gruber-Dorninger, C.; Novak, B.; Nagl, V.; Berthiller, F. Emerging mycotoxins: Beyond traditionally determined food contaminants. J. Agric. Food Chem. 2016. [CrossRef] [PubMed] 
8. Streit, E.; Schwab, C.; Sulyok, M.; Naehrer, K.; Krska, R.; Schatzmayr, G. Multi-mycotoxin screening reveals the occurrence of 139 different secondary metabolites in feed and feed ingredients. Toxins (Basel) 2013, 5, 504-523. [CrossRef] [PubMed]

9. Groschwitz, K.R.; Hogan, S.P. Intestinal barrier function: Molecular regulation and disease pathogenesis. J. Allergy Clin. Immunol. 2009, 124, 3-20. [CrossRef] [PubMed]

10. Odenwald, M.A.; Turner, J.R. Intestinal permeability defects: Is it time to treat? Clin. Gastroenterol. Hepatol. 2013, 11, 1075-1083. [CrossRef] [PubMed]

11. Akbari, P.; Braber, S.; Gremmels, H.; Koelink, P.J.; Verheijden, K.A.; Garssen, J.; Fink-Gremmels, J. Deoxynivalenol: A trigger for intestinal integrity breakdown. FASEB J. 2014, 28, 2414-2429. [CrossRef] [PubMed]

12. Sergent, T.; Parys, M.; Garsou, S.; Pussemier, L.; Schneider, Y.J.; Larondelle, Y. Deoxynivalenol transport across human intestinal Caco-2 cells and its effects on cellular metabolism at realistic intestinal concentrations. Toxicol. Lett. 2006, 164, 167-176. [CrossRef] [PubMed]

13. Pinton, P.; Braicu, C.; Nougayrede, J.P.; Laffitte, J.; Taranu, I.; Oswald, I.P. Deoxynivalenol impairs porcine intestinal barrier function and decreases the protein expression of claudin- 4 through a mitogen-activated protein kinase-dependent mechanism. J. Nutr. 2010, 140, 1956-1962. [CrossRef] [PubMed]

14. Pinton, P.; Nougayrede, J.P.; del Rio, J.C.; Moreno, C.; Marin, D.E.; Ferrier, L.; Bracarense, A.P.; Kolf-Clauw, M.; Oswald, I.P. The food contaminant deoxynivalenol, decreases intestinal barrier permeability and reduces claudin expression. Toxicol. Appl. Pharmacol. 2009, 237, 41-48. [CrossRef] [PubMed]

15. Diesing, A.K.; Nossol, C.; Danicke, S.; Walk, N.; Post, A.; Kahlert, S.; Rothkotter, H.J.; Kluess, J. Vulnerability of polarised intestinal porcine epithelial cells to mycotoxin deoxynivalenol depends on the route of application. PLoS ONE 2011, 6. [CrossRef] [PubMed]

16. Goossens, J.; Pasmans, F.; Verbrugghe, E.; Vandenbroucke, V.; De Baere, S.; Meyer, E.; Haesebrouck, F.; De Backer, P.; Croubels, S. Porcine intestinal epithelial barrier disruption by the Fusarium mycotoxins deoxynivalenol and T-2 toxin promotes transepithelial passage of doxycycline and paromomycin. BMC Vet. Res. 2012, 8. [CrossRef] [PubMed]

17. EFSA. Panel on Contaminants in the Food Chain (CONTAM). Scientific opinion on the risks to human and animal health related to the presence of beauvericin and enniatins in food and feed. EFSA J. 2014, 12, 3802.

18. Kamyar, M.; Rawnduzi, P.; Studenik, C.R.; Kouri, K.; Lemmens-Gruber, R. Investigation of the electrophysiological properties of enniatins. Arch. Biochem. Biophys. 2004, 429, 215-223. [CrossRef] [PubMed]

19. Kouri, K.; Duchen, M.R.; Lemmens-Gruber, R. Effects of beauvericin on the metabolic state and ionic homeostasis of ventricular myocytes of the guinea pig. Chem. Res. Toxicol. 2005, 18, 1661-1668. [CrossRef] [PubMed]

20. Kouri, K.; Lemmens, M.; Lemmens-Gruber, R. Beauvericin-induced channels in ventricular myocytes and liposomes. Biochim. Biophys. Acta 2003, 1609, 203-210. [CrossRef]

21. Meca, G.; Font, G.; Ruiz, M.J. Comparative cytotoxicity study of enniatins A, A(1), A(2), B, B(1), B(4) and J(3) on Caco-2 cells, Hep-G(2) and HT-29. Food Chem. Toxicol. 2011, 49, 2464-2469. [CrossRef] [PubMed]

22. Dornetshuber, R.; Heffeter, P.; Kamyar, M.R.; Peterbauer, T.; Berger, W.; Lemmens-Gruber, R. Enniatin exerts p53-dependent cytostatic and p53-independent cytotoxic activities against human cancer cells. Chem. Res. Toxicol. 2007, 20, 465-473. [CrossRef] [PubMed]

23. Lee, H.S.; Song, H.H.; Jeong, J.H.; Shin, C.G.; Choi, S.U.; Lee, C. Cytotoxicities of enniatins H, I, and MK1688 from Fusarium oxysporum KFCC 11363P. Toxicon 2008, 51, 1178-1185. [CrossRef] [PubMed]

24. Fornelli, F.; Minervini, F.; Logrieco, A. Cytotoxicity of fungal metabolites to lepidopteran (Spodoptera frugiperda) cell line (SF-9). J. Invertebr. Pathol. 2004, 85, 74-79. [CrossRef] [PubMed]

25. Ivanova, L.; Skjerve, E.; Eriksen, G.S.; Uhlig, S. Cytotoxicity of enniatins A, A1, B, B1, B2 and B3 from Fusarium avenaceum. Toxicon 2006, 47, 868-876. [CrossRef] [PubMed]

26. Zhan, J.; Burns, A.M.; Liu, M.X.; Faeth, S.H.; Gunatilaka, A.A. Search for cell motility and angiogenesis inhibitors with potential anticancer activity: Beauvericin and other constituents of two endophytic strains of Fusarium oxysporum. J. Nat. Prod. 2007, 70, 227-232. [CrossRef] [PubMed]

27. Tonshin, A.A.; Teplova, V.V.; Andersson, M.A.; Salkinoja-Salonen, M.S. The Fusarium mycotoxins enniatins and beauvericin cause mitochondrial dysfunction by affecting the mitochondrial volume regulation, oxidative phosphorylation and ion homeostasis. Toxicology 2010, 276, 49-57. [CrossRef] [PubMed] 
28. Lin, H.I.; Lee, Y.J.; Chen, B.F.; Tsai, M.C.; Lu, J.L.; Chou, C.J.; Jow, G.M. Involvement of Bcl-2 family, cytochrome $\mathrm{c}$ and caspase 3 in induction of apoptosis by beauvericin in human non-small cell lung cancer cells. Cancer Lett. 2005, 230, 248-259. [CrossRef] [PubMed]

29. Gammelsrud, A.; Solhaug, A.; Dendele, B.; Sandberg, W.J.; Ivanova, L.; Kocbach Bolling, A.; Lagadic-Gossmann, D.; Refsnes, M.; Becher, R.; Eriksen, G.; et al. Enniatin B-induced cell death and inflammatory responses in RAW 267.4 murine macrophages. Toxicol. Appl. Pharmacol. 2012, 261, $74-87$. [CrossRef] [PubMed]

30. Ivanova, L.; Egge-Jacobsen, W.M.; Solhaug, A.; Thoen, E.; Faeste, C.K. Lysosomes as a possible target of enniatin B-induced toxicity in Caco-2 cells. Chem. Res. Toxicol. 2012, 25, 1662-1674. [CrossRef] [PubMed]

31. Watjen, W.; Debbab, A.; Hohlfeld, A.; Chovolou, Y.; Proksch, P. The mycotoxin beauvericin induces apoptotic cell death in H4IIE hepatoma cells accompanied by an inhibition of NF-kappaB-activity and modulation of MAP-kinases. Toxicol. Lett. 2014, 231, 9-16. [CrossRef] [PubMed]

32. Prosperini, A.; Juan-Garcia, A.; Font, G.; Ruiz, M.J. Reactive oxygen species involvement in apoptosis and mitochondrial damage in Caco-2 cells induced by enniatins A, A(1), B and B(1). Toxicol. Lett. 2013, 222, $36-44$. [CrossRef] [PubMed]

33. Dornetshuber, R.; Heffeter, P.; Lemmens-Gruber, R.; Elbling, L.; Marko, D.; Micksche, M.; Berger, W. Oxidative stress and DNA interactions are not involved in Enniatin- and Beauvericin-mediated apoptosis induction. Mol. Nutr. Food Res. 2009, 53, 1112-1122. [CrossRef] [PubMed]

34. Mallebrera, B.; Font, G.; Ruiz, M.J. Disturbance of antioxidant capacity produced by beauvericin in CHO-K1 cells. Toxicol. Lett. 2014, 226, 337-342. [CrossRef] [PubMed]

35. Tomoda, H.; Huang, X.H.; Cao, J.; Nishida, H.; Nagao, R.; Okuda, S.; Tanaka, H.; Omura, S.; Arai, H.; Inoue, K. Inhibition of acyl-CoA: Cholesterol acyltransferase activity by cyclodepsipeptide antibiotics. J. Antibiot. (Tokyo) 1992, 45, 1626-1632. [CrossRef] [PubMed]

36. Rodriguez-Carrasco, Y.; Heilos, D.; Richter, L.; Sussmuth, R.D.; Heffeter, P.; Sulyok, M.; Kenner, L.; Berger, W.; Dornetshuber-Fleiss, R. Mouse tissue distribution and persistence of the food-born fusariotoxins Enniatin B and Beauvericin. Toxicol. Lett. 2016, 247, 35-44. [CrossRef] [PubMed]

37. Juan, C.; Manyes, L.; Font, G.; Juan-Garcia, A. Evaluation of immunologic effect of Enniatin A and quantitative determination in feces, urine and serum on treated Wistar rats. Toxicon 2014, 87, 45-53. [CrossRef] [PubMed]

38. Manyes, L.; Escriva, L.; Serrano, A.B.; Rodriguez-Carrasco, Y.; Tolosa, J.; Meca, G.; Font, G. A preliminary study in Wistar rats with enniatin A contaminated feed. Toxicol. Mech. Methods 2014, 24, 179-190. [CrossRef] [PubMed]

39. Leitgeb, R.; Lew, H.; Khidr, R.; Böhm, J.; Zollitsch, W.; Wagner, E. Influence of Fusarium toxins on growth and carcass characteristics of turkeys. Die Bodenkult. 2000, 51, 171-178.

40. Leitgeb, R.; Lew, H.; Wetscherek, W.; Böhm, J.; Quinz, A. Influence of fusariotoxins on growing and slaughtering performance of broilers. Die Bodenkult. 1999, 50, 57-66.

41. Leitgeb, R.; Raffaseder, C.; Ruckenbauer, P.; Lemmens, M.; Bohm, J.; Wagner, E.; Krska, R.; Parich, A. Impact of fusarium toxins on growth and slaughter performance of broilers and turkeys. Mycotoxin Res. 2003, 19, 180-184. [CrossRef] [PubMed]

42. Zollitsch, W.; Raffaseder, C.; Böhm, J.; Wagner, W.; Leitgeb, R. Impact of the mycotoxins moniliformin and beauvericin on growh and carcass traits of broilers. Wien. Tierärztliche Mschr. 2003, 90, 238-243.

43. McKee, T.C.; Bokesch, H.R.; McCormick, J.L.; Rashid, M.A.; Spielvogel, D.; Gustafson, K.R.; Alavanja, M.M.; Cardelline, J.H., 2nd; Boyd, M.R. Isolation and characterization of new anti-HIV and cytotoxic leads from plants, marine, and microbial organisms. J. Nat. Prod. 1997, 60, 431-438. [CrossRef] [PubMed]

44. Bauden, M.; Tassidis, H.; Ansari, D. In vitro cytotoxicity evaluation of HDAC inhibitor Apicidin in pancreatic carcinoma cells subsequent time and dose dependent treatment. Toxicol. Lett. 2015, 236, 8-15. [CrossRef] [PubMed]

45. Bradner, J.E.; West, N.; Grachan, M.L.; Greenberg, E.F.; Haggarty, S.J.; Warnow, T.; Mazitschek, R. Chemical phylogenetics of histone deacetylases. Nat. Chem. Biol. 2010, 6, 238-243. [CrossRef] [PubMed]

46. Darkin-Rattray, S.J.; Gurnett, A.M.; Myers, R.W.; Dulski, P.M.; Crumley, T.M.; Allocco, J.J.; Cannova, C.; Meinke, P.T.; Colletti, S.L.; Bednarek, M.A.; et al. Apicidin: A novel antiprotozoal agent that inhibits parasite histone deacetylase. Proc. Natl. Acad. Sci. USA 1996, 93, 13143-13147. [CrossRef] [PubMed] 
47. Choudhary, C.; Kumar, C.; Gnad, F.; Nielsen, M.L.; Rehman, M.; Walther, T.C.; Olsen, J.V.; Mann, M. Lysine acetylation targets protein complexes and co-regulates major cellular functions. Science 2009, 325, 834-840. [CrossRef] [PubMed]

48. Tang, J.; Yan, H.; Zhuang, S. Histone deacetylases as targets for treatment of multiple diseases. Clin. Sci. (Lond.) 2013, 124, 651-662. [CrossRef] [PubMed]

49. Ahn, M.Y.; Ahn, J.W.; Kim, H.S.; Lee, J.; Yoon, J.H. Apicidin inhibits cell growth by downregulating IGF-1R in salivary mucoepidermoid carcinoma cells. Oncol. Rep. 2015, 33, 1899-1907. [CrossRef] [PubMed]

50. Ahn, M.Y.; Lee, J.; Na, Y.J.; Choi, W.S.; Lee, B.M.; Kang, K.W.; Kim, H.S. Mechanism of apicidin-induced cell cycle arrest and apoptosis in Ishikawa human endometrial cancer cells. Chem. Biol. Interact. 2009, 179, 169-177. [CrossRef] [PubMed]

51. Park, J.S.; Lee, K.R.; Kim, J.C.; Lim, S.H.; Seo, J.A.; Lee, Y.W. A hemorrhagic factor (Apicidin) produced by toxic Fusarium isolates from soybean seeds. Appl. Environ. Microbiol. 1999, 65, 126-130. [PubMed]

52. Vejdovszky, K.; Warth, B.; Sulyok, M.; Marko, D. Non-synergistic cytotoxic effects of Fusarium and Alternaria toxin combinations in Caco-2 cells. Toxicol. Lett. 2015, 241, 1-8. [CrossRef] [PubMed]

53. Dvorska, J.E.; Surai, P.F.; Speake, B.K.; Sparks, N.H. Effect of the mycotoxin aurofusarin on the antioxidant composition and fatty acid profile of quail eggs. Br. Poult. Sci. 2001, 42, 643-649. [CrossRef] [PubMed]

54. Dvorska, J.E.; Surai, P.F.; Speake, B.K.; Sparks, N.H. Antioxidant systems of the developing quail embryo are compromised by mycotoxin aurofusarin. Comp. Biochem. Physiol. C Toxicol. Pharmacol. 2002, 131, 197-205. [CrossRef]

55. Dvorska, J.E. Effect of Dimeric Naphthoquinone Aurofusarin on Chicken Meat Quality. In Proceedings of the 21st World's Poultry Congress, Montreal, QC, Canada, 20-24 August 2000; pp. 46-49.

56. Branco, A.; Pinto, A.C.; Braz-Filho, R.; Silva, E.F.; Grynberg, N.F.; Echevarria, A. Rubrofusarin, a natural polyketide as new human topoisomerase II- $\alpha$ inhibitor. Rev. Bras. Farmacogn. 2008, 18, 703-708. [CrossRef]

57. Desjardins, A.E.; Proctor, R.H. Molecular biology of Fusarium mycotoxins. Int. J. Food Microbiol. 2007, 119, 47-50. [CrossRef] [PubMed]

58. Kjaer, D.; Kjaer, A.; Pedersen, C.; Bu'lock, J.D.; Smith, J.R. Bikaverin and norbikaverin, benzoxanthentrione pigments of Gibberella fujikuroi. J. Chem. Soc. Perkin 1 1971, 16, 2792-2797. [CrossRef] [PubMed]

59. Linnemannstons, P.; Schulte, J.; del Mar Prado, M.; Proctor, R.H.; Avalos, J.; Tudzynski, B. The polyketide synthase gene pks4 from Gibberella fujikuroi encodes a key enzyme in the biosynthesis of the red pigment bikaverin. Fungal Genet. Biol. 2002, 37, 134-148. [CrossRef]

60. Fuska, J.; Proksa, B.; Fuskova, A. New potential cytotoxic and antitumor substances I. In vitro effect of bikaverin and its derivatives on cells of certain tumors. Neoplasma 1975, 22, 335-338. [PubMed]

61. Thiel, P.G. A molecular mechanism for the toxic action of moniliformin, a mycotoxin produced by Fusarium moniliforme. Biochem. Pharmacol. 1978, 27, 483-486. [CrossRef]

62. Ficheux, A.S.; Sibiril, Y.; Le Garrec, R.; Parent-Massin, D. In vitro myelotoxicity assessment of the emerging mycotoxins Beauvericin, Enniatin b and Moniliformin on human hematopoietic progenitors. Toxicon 2012, 59, 182-191. [CrossRef] [PubMed]

63. Cetin, Y.; Bullerman, L.B. Cytotoxicity of Fusarium mycotoxins to mammalian cell cultures as determined by the MTT bioassay. Food Chem. Toxicol. 2005, 43, 755-764. [CrossRef] [PubMed]

64. Wu, W.; Liu, T.; Vesonder, R.F. Comparative cytotoxicity of fumonisin B1 and moniliformin in chicken primary cell cultures. Mycopathologia 1995, 132, 111-116. [CrossRef] [PubMed]

65. Celik, M.; Yilmaz, S.; Aksoy, H.; Unal, F.; Yuzbasioglu, D.; Donbak, L. Evaluation of the genotoxicity of Fusarium mycotoxin moniliformin in human peripheral blood lymphocytes. Environ. Mol. Mutagen. 2009, 50, 431-434. [CrossRef] [PubMed]

66. Knasmuller, S.; Bresgen, N.; Kassie, F.; Mersch-Sundermann, V.; Gelderblom, W.; Zohrer, E.; Eckl, P.M. Genotoxic effects of three Fusarium mycotoxins, fumonisin B1, moniliformin and vomitoxin in bacteria and in primary cultures of rat hepatocytes. Mutat. Res. 1997, 391, 39-48. [CrossRef]

67. Norred, W.P.; Plattner, R.D.; Vesonder, R.F.; Bacon, C.W.; Voss, K.A. Effects of selected secondary metabolites of Fusarium moniliforme on unscheduled synthesis of DNA by rat primary hepatocytes. Food Chem. Toxicol. 1992, 30, 233-237. [CrossRef]

68. Cole, R.J.; Kirksey, J.W.; Cutler, H.G.; Doupnik, B.L.; Peckham, J.C. Toxin from Fusarium moniliforme: Effects on Plants and Animals. Science 1973, 179, 1324-1326. [CrossRef] [PubMed] 
69. Morgan, M.K.; Fitzgerald, S.D.; Rottinghaus, G.E.; Bursian, S.J.; Aulerich, R.J. Toxic effects to mink of moniliformin extracted from Fusarium fujikuroi culture material. Vet. Hum. Toxicol. 1999, 41, 1-5. [PubMed]

70. Allen, N.K.; Burmeister, H.R.; Weaver, G.A.; Mirocha, C.J. Toxicity of dietary and intravenously administered moniliformin to broiler chickens. Poult. Sci. 1981, 60, 1415-1417. [CrossRef] [PubMed]

71. Burmeister, H.R.; Ciegler, A.; Vesonder, R.F. Moniliformin, a metabolite of Fusarium moniliforme NRRL 6322: Purification and toxicity. Appl. Environ. Microbiol. 1979, 37, 11-13. [PubMed]

72. Kriek, N.P.; Marasas, W.F.; Steyn, P.S.; van Rensburg, S.J.; Steyn, M. Toxicity of a moniliformin-producing strain of Fusarium moniliforme var. subglutinans isolated from maize. Food Cosmet. Toxicol. 1977, 15, 579-587. [CrossRef]

73. Jonsson, M.; Jestoi, M.; Nathanail, A.V.; Kokkonen, U.M.; Anttila, M.; Koivisto, P.; Karhunen, P.; Peltonen, K. Application of OECD Guideline 423 in assessing the acute oral toxicity of moniliformin. Food Chem. Toxicol. 2013, 53, 27-32. [CrossRef] [PubMed]

74. Bermudez, A.J.; Ledoux, D.R.; Rottinghaus, G.E.; Bennett, G.A. The individual and combined effects of the Fusarium mycotoxins moniliformin and fumonisin B1 in turkeys. Avian Dis. 1997, 41, 304-311. [CrossRef] [PubMed]

75. Li, Y.C.; Ledoux, D.R.; Bermudez, A.J.; Fritsche, K.L.; Rottinghaus, G.E. The individual and combined effects of fumonisin B1 and moniliformin on performance and selected immune parameters in turkey poults. Poult. Sci. 2000, 79, 871-878. [CrossRef] [PubMed]

76. European Union. Commission Regulation (EC) No 1881/2006 of 19 December 2006 Setting Maximum Levels for Certain Contaminants in Foodstuffs; Food and Agriculture Organization of the United States: Washinghton, DC, USA, 2006.

77. Jestoi, M. Emerging fusarium-mycotoxins fusaproliferin, beauvericin, enniatins, and moniliformin: A review. Crit. Rev. Food Sci. Nutr. 2008, 48, 21-49. [CrossRef] [PubMed]

78. Bottalico, A.; Logrieco, A.; Ritieni, A.; Moretti, A.; Randazzo, G.; Corda, P. Beauvericin and fumonisin B1 in preharvest Fusarium moniliforme maize ear rot in Sardinia. Food Addit. Contam. 1995, 12, 599-607. [CrossRef] [PubMed]

79. Munkvold, G.; Stahr, H.M.; Logrieco, A.; Moretti, A.; Ritieni, A. Occurrence of fusaproliferin and beauvericin in Fusarium-contaminated livestock feed in Iowa. Appl. Environ. Microbiol. 1998, 64, 3923-3926. [PubMed]

80. Jestoi, M.; Rokka, M.; Yli-Mattila, T.; Parikka, P.; Rizzo, A.; Peltonen, K. Presence and concentrations of the Fusarium-related mycotoxins beauvericin, enniatins and moniliformin in finnish grain samples. Food Addit. Contam. 2004, 21, 794-802. [CrossRef] [PubMed]

81. Uhlig, S.; Torp, M.; Heier, B.T. Beauvericin and enniatins A, A1, B, and B1 in Norwegian grain: A survey. Food Chem. 2006, 94, 193-201. [CrossRef]

82. Malachova, A.; Dzuman, Z.; Veprikova, Z.; Vaclavikova, M.; Zachariasova, M.; Hajslova, J. Deoxynivalenol, deoxynivalenol-3-glucoside, and enniatins: The major mycotoxins found in cereal-based products on the Czech market. J. Agric. Food Chem. 2011, 59, 12990-12997. [CrossRef] [PubMed]

83. Juan, C.; Ritieni, A.; Manes, J. Occurrence of Fusarium mycotoxins in Italian cereal and cereal products from organic farming. Food Chem. 2013, 141, 1747-1755. [CrossRef] [PubMed]

84. Lindblad, M.; Gidlund, A.; Sulyok, M.; Borjesson, T.; Krska, R.; Olsen, M.; Fredlund, E. Deoxynivalenol and other selected Fusarium toxins in Swedish wheat-Occurrence and correlation to specific Fusarium species. Int. J. Food Microbiol. 2013, 167, 284-291. [CrossRef] [PubMed]

85. Mikusova, P.; Srobarova, A.; Sulyok, M.; Santini, A. Fusarium fungi and associated metabolites presence on grapes from Slovakia. Mycotoxin Res. 2013, 29, 97-102. [CrossRef] [PubMed]

86. Shimshoni, J.A.; Cuneah, O.; Sulyok, M.; Krska, R.; Galon, N.; Sharir, B.; Shlosberg, A. Mycotoxins in corn and wheat silage in Israel. Food Addit. Contam. Part A Chem. Anal. Control. Expo. Risk Assess. 2013, 30, 1614-1625. [CrossRef] [PubMed]

87. Springler, A.; Hessenberger, S.; Schatzmayr, G.; Mayer, E. Early Activation of MAPK p44/42 Is Partially Involved in DON-Induced Disruption of the Intestinal Barrier Function and Tight Junction Network. Toxins 2016, 8. [CrossRef] [PubMed]

88. Pinton, P.; Oswald, I.P. Effect of deoxynivalenol and other Type B trichothecenes on the intestine: A review. Toxins (Basel) 2014, 6, 1615-1643. [CrossRef] [PubMed]

89. Maresca, M. From the gut to the brain: Journey and pathophysiological effects of the food-associated trichothecene mycotoxin deoxynivalenol. Toxins (Basel) 2013, 5, 784-820. [CrossRef] [PubMed] 
90. Romero, A.; Ares, I.; Ramos, E.; Castellano, V.; Martinez, M.; Martinez-Larranaga, M.R.; Anadon, A.; Martinez, M.A. Mycotoxins modify the barrier function of Caco-2 cells through differential gene expression of specific claudin isoforms: Protective effect of illite mineral clay. Toxicology 2016, 353-354, 21-33. [CrossRef] [PubMed]

91. Chen, X.; Naehrer, K.; Applegate, T.J. Interactive effects of dietary protein concentration and aflatoxin B1 on performance, nutrient digestibility, and gut health in broiler chicks. Poult. Sci. 2016, 95, 1312-1325. [CrossRef] [PubMed]

92. Marin, D.E.; Motiu, M.; Taranu, I. Food contaminant zearalenone and its metabolites affect cytokine synthesis and intestinal epithelial integrity of porcine cells. Toxins (Basel) 2015, 7, 1979-1988. [CrossRef] [PubMed]

93. Liu, M.; Gao, R.; Meng, Q.; Zhang, Y.; Bi, C.; Shan, A. Toxic effects of maternal zearalenone exposure on intestinal oxidative stress, barrier function, immunological and morphological changes in rats. PLoS ONE 2014, 9. [CrossRef] [PubMed]

94. McLaughlin, J.; Padfield, P.J.; Burt, J.P.; O’Neill, C.A. Ochratoxin A increases permeability through tight junctions by removal of specific claudin isoforms. Am. J. Physiol. Cell Physiol. 2004, 287, C1412-C1417. [CrossRef] [PubMed]

95. Maresca, M.; Mahfoud, R.; Pfohl-Leszkowicz, A.; Fantini, J. The mycotoxin ochratoxin A alters intestinal barrier and absorption functions but has no effect on chloride secretion. Toxicol. Appl. Pharmacol. 2001, 176, 54-63. [CrossRef] [PubMed]

96. McLaughlin, J.; Lambert, D.; Padfield, P.J.; Burt, J.P.; O'Neill, C.A. The mycotoxin patulin, modulates tight junctions in caco-2 cells. Toxicol. In Vitro 2009, 23, 83-89. [CrossRef] [PubMed]

97. Mohan, H.M.; Collins, D.; Maher, S.; Walsh, E.G.; Winter, D.C.; O'Brien, P.J.; Brayden, D.J.; Baird, A.W. The mycotoxin patulin increases colonic epithelial permeability in vitro. Food Chem. Toxicol. 2012, 50, 4097-4102. [CrossRef] [PubMed]

98. Bouhet, S.; Hourcade, E.; Loiseau, N.; Fikry, A.; Martinez, S.; Roselli, M.; Galtier, P.; Mengheri, E.; Oswald, I.P. The mycotoxin fumonisin B1 alters the proliferation and the barrier function of porcine intestinal epithelial cells. Toxicol. Sci. 2004, 77, 165-171. [CrossRef] [PubMed]

99. Bouhet, S.; Oswald, I.P. The intestine as a possible target for fumonisin toxicity. Mol. Nutr. Food Res. 2007, 51, 925-931. [CrossRef] [PubMed]

100. Bracarense, A.P.; Lucioli, J.; Grenier, B.; Drociunas Pacheco, G.; Moll, W.D.; Schatzmayr, G.; Oswald, I.P. Chronic ingestion of deoxynivalenol and fumonisin, alone or in interaction, induces morphological and immunological changes in the intestine of piglets. Br. J. Nutr. 2012, 107, 1776-1786. [CrossRef] [PubMed]

101. Verbrugghe, E.; Vandenbroucke, V.; Dhaenens, M.; Shearer, N.; Goossens, J.; De Saeger, S.; Eeckhout, M.; D'Herde, K.; Thompson, A.; Deforce, D.; et al. T-2 toxin induced Salmonella Typhimurium intoxication results in decreased Salmonella numbers in the cecum contents of pigs, despite marked effects on Salmonella-host cell interactions. Vet. Res. 2012, 43. [CrossRef] [PubMed]

102. Schierack, P.; Nordhoff, M.; Pollmann, M.; Weyrauch, K.D.; Amasheh, S.; Lodemann, U.; Jores, J.; Tachu, B.; Kleta, S.; Blikslager, A.; et al. Characterization of a porcine intestinal epithelial cell line for in vitro studies of microbial pathogenesis in swine. Histochem. Cell Biol. 2006, 125, 293-305. [CrossRef] [PubMed]

103. Berschneider, H.M. Development of normal cultured small intestinal epithelial cell lines which transport $\mathrm{Na}$ and Cl. Gastroenterology 1989, 96, A41.

104. Nossol, C.; Barta-Boszormenyi, A.; Kahlert, S.; Zuschratter, W.; Faber-Zuschratter, H.; Reinhardt, N.; Ponsuksili, S.; Wimmers, K.; Diesing, A.K.; Rothkotter, H.J. Comparing Two Intestinal Porcine Epithelial Cell Lines (IPECs): Morphological Differentiation, Function and Metabolism. PLoS ONE 2015, 10. [CrossRef] [PubMed]

105. Meca, G.; Zinedine, A.; Blesa, J.; Font, G.; Manes, J. Further data on the presence of Fusarium emerging mycotoxins enniatins, fusaproliferin and beauvericin in cereals available on the Spanish markets. Food Chem. Toxicol. 2010, 48, 1412-1416. [CrossRef] [PubMed]

106. Prosperini, A.; Font, G.; Ruiz, M.J. Interaction effects of Fusarium enniatins (A, A1, B and B1) combinations on in vitro cytotoxicity of Caco-2 cells. Toxicol. In Vitro 2014, 28, 88-94. [CrossRef] [PubMed]

107. Tai, Y.H.; Flick, J.; Levine, S.A.; Madara, J.L.; Sharp, G.W.; Donowitz, M. Regulation of tight junction resistance in T84 monolayers by elevation in intracellular Ca2+: A protein kinase C effect. J. Membr. Biol. 1996, 149, 71-79. [PubMed] 
108. Kan, K.S.; Coleman, R. The calcium ionophore A23187 increases the tight-junctional permeability in rat liver. Biochem. J. 1988, 256, 1039-1041. [CrossRef] [PubMed]

109. Lu, C.L.; Lin, H.I.; Chen, B.F.; Jow, G.M. Beauvericin-induced cell apoptosis through the mitogen-activated protein kinase pathway in human nonsmall cell lung cancer A549 cells. J. Toxicol. Sci. 2016, 41, 429-437. [CrossRef] [PubMed]

110. Han, J.W.; Ahn, S.H.; Park, S.H.; Wang, S.Y.; Bae, G.U.; Seo, D.W.; Kwon, H.K.; Hong, S.; Lee, H.Y.; Lee, Y.W.; et al. Apicidin, a histone deacetylase inhibitor, inhibits proliferation of tumor cells via induction of p21WAF1/Cip1 and gelsolin. Cancer Res 2000, 60, 6068-6074. [PubMed]

111. Krishnan, M.; Singh, A.B.; Smith, J.J.; Sharma, A.; Chen, X.; Eschrich, S.; Yeatman, T.J.; Beauchamp, R.D.; Dhawan, P. HDAC inhibitors regulate claudin-1 expression in colon cancer cells through modulation of mRNA stability. Oncogene 2010, 29, 305-312. [CrossRef] [PubMed]

112. Dvorska, J.E.; Surai, P.F.; Speake, B.K.; Sparks, N.H. Protective effect of modified glucomannans against aurofusarin-induced changes in quail egg and embryo. Comp. Biochem. Physiol. C Toxicol. Pharmacol. 2003, 135C, 337-343. [CrossRef]

113. Ficheux, A.S.; Sibiril, Y.; Parent-Massin, D. Effects of beauvericin, enniatin b and moniliformin on human dendritic cells and macrophages: An in vitro study. Toxicon 2013, 71, 1-10. [CrossRef] [PubMed]

114. Speijers, G.J.; Speijers, M.H. Combined toxic effects of mycotoxins. Toxicol. Lett. 2004, 153, 91-98. [CrossRef] [PubMed]

115. Kouadio, J.H.; Dano, S.D.; Moukha, S.; Mobio, T.A.; Creppy, E.E. Effects of combinations of Fusarium mycotoxins on the inhibition of macromolecular synthesis, malondialdehyde levels, DNA methylation and fragmentation, and viability in Caco-2 cells. Toxicon 2007, 49, 306-317. [CrossRef] [PubMed]

116. Ruiz, M.J.; Macakova, P.; Juan-Garcia, A.; Font, G. Cytotoxic effects of mycotoxin combinations in mammalian kidney cells. Food Chem. Toxicol. 2011, 49, 2718-2724. [CrossRef] [PubMed]

117. Ruiz, M.J.; Franzova, P.; Juan-Garcia, A.; Font, G. Toxicological interactions between the mycotoxins beauvericin, deoxynivalenol and T-2 toxin in CHO-K1 cells in vitro. Toxicon 2011, 58, 315-326. [CrossRef] [PubMed]

118. Chou, T.C. Theoretical basis, experimental design, and computerized simulation of synergism and antagonism in drug combination studies. Pharmacol. Rev. 2006, 58, 621-681. [CrossRef] [PubMed]

119. Chou, T.C.; Talalay, P. Quantitative analysis of dose-effect relationships: The combined effects of multiple drugs or enzyme inhibitors. Adv. Enzym. Regul. 1984, 22, 27-55. [CrossRef]

120. Visconti, A.; Minervini, F.; Lucivero, G.; Gambatesa, V. Cytotoxic and immunotoxic effects of Fusarium mycotoxins using a rapid colorimetric bioassay. Mycopathologia 1991, 113, 181-186. [CrossRef] [PubMed] 